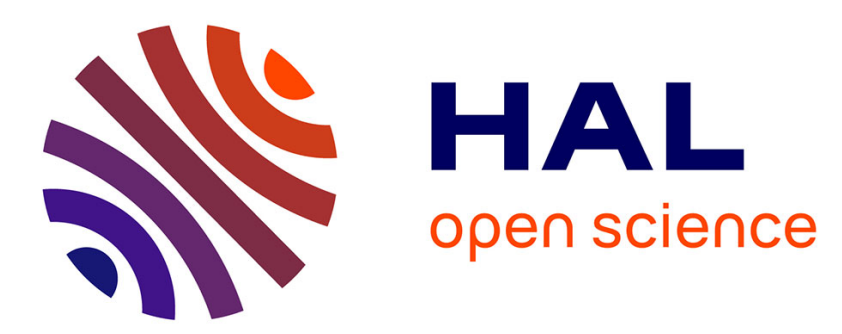

\title{
Self-Defensive Biomaterial Coating Against Bacteria and Yeasts: Polysaccharide Multilayer Film with Embedded Antimicrobial Peptide
}

\author{
G. Cado, R. Aslam, L. Séon, T. Garnier, R. Fabre, A. Parat, A. Chassepot, \\ J.-C. Voegel, B. Senger, F. Schneider, et al.
}

\section{To cite this version:}

G. Cado, R. Aslam, L. Séon, T. Garnier, R. Fabre, et al.. Self-Defensive Biomaterial Coating Against Bacteria and Yeasts: Polysaccharide Multilayer Film with Embedded Antimicrobial Peptide. Advanced Functional Materials, 2013, pp.n/a-n/a. 10.1002/adfm.201300416 . hal-02163993

\section{HAL Id: hal-02163993 https://hal.science/hal-02163993}

Submitted on 27 Jan 2020

HAL is a multi-disciplinary open access archive for the deposit and dissemination of scientific research documents, whether they are published or not. The documents may come from teaching and research institutions in France or abroad, or from public or private research centers.
L'archive ouverte pluridisciplinaire HAL, est destinée au dépôt et à la diffusion de documents scientifiques de niveau recherche, publiés ou non, émanant des établissements d'enseignement et de recherche français ou étrangers, des laboratoires publics ou privés. 
DOI: 10.1002/adfm. (please insert DOI)

Submitted to

\section{Self-defensive biomaterial coating against bacteria and yeasts: polysaccharide multilayer film with embedded antimicrobial peptide}

By G. Cado ${ }^{+}$, R. Aslam ${ }^{+}$, L. Séon,+ T. Garnier, R. Fabre, A. Parat, A. Chassepot, J.-C. Voegel, B. Senger, F. Schneider, Y. Frère, L. Jierry, P. Schaaf, H. Kerdjoudj, M.-H. Metz-Boutigue and F. Boulmedais*

+ These authors contributed equally

10

[*] Dr. F. Boulmedais and Prof. P. Schaaf, Corresponding-Authors, Dr. G. Cado, L. Séon, Dr. T. Garnier, Dr. A. Parat, Dr. Y. Frère, Dr. L. Jierry

Centre National de la Recherche Scientifique, Institut Charles Sadron, UPR 22, 23 rue du Loess, 67034 Strasbourg Cedex 2, France. E-mail: fouzia.boulmedais@ics-cnrs.unistra.fr and pierre.schaaf@unistra.fr

Prof. P. Schaaf, R. Aslam, Dr. R. Fabre, A. Chassepot, Dr. J.-C. Voegel, Dr. B. Senger, Dr M.-H. Metz-Boutigue

Institut National de la Santé et de la Recherche Médicale, INSERM UMR 1121, 11 rue Humann, 67085 Strasbourg Cedex, France

20 Université de Strasbourg, Faculté de Chirurgie Dentaire, 1 place de l'Hôpital, 67000 Strasbourg, France.

Prof. F. Schneider

Service de Réanimation Médicale, Hôpital de Hautepierre, Hôpitaux Universitaires de Strasbourg, 1 avenue Molière, 67098 Strasbourg Cedex, France.

Dr. H. Kerdjoudj

EA 4691, Université de Reims Champagne Ardenne, SFR-CapSanté, 1 avenue du Maréchal Juin, 51100 Reims.

Dr. L. Jierry, Prof. P. Schaaf

Université de Strasbourg, Ecole Européenne de Chimie, Polymères et Matériaux, 25 rue

Becquerel, 67087 Strasbourg Cedex 2, France.

Dr. L. Jierry, Prof. P. Schaaf, Dr. F. Boulmedais

International Center for Frontier Research in Chemistry, 8 allée Gaspard Monge, 67083

Strasbourg, France.

Prof. P. Schaaf

Institut Universitaire de France, 103 boulevard Saint-Michel, 75005 Paris, France.

Keywords: layer-by-layer, chitosan, hyaluronic acid/hyaluronan, fibroblasts, cateslytin 


\section{Abstract}

Submitted to

Prevention of pathogen colonization of medical implants is a major medical and financial issue since infection by microorganisms constitutes one of the most serious complications after surgery or critical care. Immobilization of antimicrobial molecules on biomaterials surfaces is an efficient approach to prevent biofilm formation. To the best of our knowledge, we developed herein the first self-defensive coating against both bacteria and yeasts where the release of the antimicrobial peptide is triggered by enzymatic degradation of the film due to the pathogens themselves. Biocompatible and biodegradable polysaccharide multilayer films based on functionalized hyaluronic acid by cateslytin (CTL), an endogenous host-defensive antimicrobial peptide, and chitosan (HA-CTL-C/CHI) were deposited on a planar surface with the aim of designing both antibacterial and antifungal coating. After $24 \mathrm{~h}$ of incubation, HACTL-C/CHI films fully inhibit the development of Gram-positive Staphylococcus aureus bacteria and Candida albicans yeasts, which are common and virulent pathogens agents encountered in care-associated diseases. Hyaluronidase, secreted by the pathogens, leads to the film degradation and the antimicrobial action of the peptide. Furthermore, the limited fibroblasts adhesion on HA-CTL-C/CHI films, without cytotoxicity, highlights a medically relevant application to prevent infections on catheters or tracheal tubes where fibrous tissue encapsulation is undesirable. 


\section{Introduction}

Submitted to

Implantable medical devices are widely used in surgery not only to replace altered or lost tissues but also in critical care for fluid or gas administration using catheters or tracheal tube, respectively. These devices constitute an open gate for pathogens invasion. ${ }^{[1]}$ Prevention of pathogen colonization of medical implants constitutes a major medical and financial issue since nosocomial infection represents one of the most serious complications after surgery or critical care. Indeed each year in Europe, 5\% of patients admitted to hospitals suffer from hospital-acquired infections leading to a mortality of $10 \% .^{[2]}$ Staphylococcus aureus (S. aureus), a Gram-positive bacterium, is responsible for hospital-acquired infections especially in immunocompromized patients. It is one of the most virulent bacteria leading to high rates of device-related systemic infections and mortality. ${ }^{[3]}$ A recent study has genetically characterized the strains of $S$. aureus responsible of catheter-related infections and demonstrated that $82 \%$ of these strains are methicillin resistant and contain numerous genes involved in biofilm formation and bacterial dispersion. ${ }^{[4]}$ Candida albicans (C. albicans), the most common human yeast pathogen, possesses the ability to form biofilms that are sources of local and systemic infection. Moreover $C$. albicans biofilms allow the formation of $S$.

75 aureus microcolonies on their surface and even enhanced $S$. aureus resistance to antibiotics. ${ }^{[5]}$ When associated with bacterial infections, fungal proliferation induces an increased frequency or severity of diseases. ${ }^{[6-8]}$ The recent resistance of $C$. albicans to antifungal therapies ${ }^{[9,10]}$ and of $S$. aureus to antibiotics points out the need of multifunctional coatings that prevent infections of both yeast and bacteria.

Various approaches based on immobilization or release of bactericidal substances, using self-assembled monolayers or grafting of polymers have been explored and extensively reviewed. ${ }^{[11,12]}$ Polyelectrolyte multilayer (PEM) films, based on an alternated deposition of polycations and polyanions onto a solid surface, emerged as a simple and efficient approach 
Submitted to 14 A

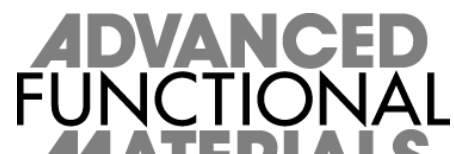

to functionalize surfaces in a controlled way. ${ }^{[13,14]}$ The first antibacterial PEM films were

85 designed by insertion of silver nanoparticles. ${ }^{[15-20]}$ Later on, hydrophobic bactericide using dendritic block copolymer ${ }^{[21]}$ and silver ion containing liposomes ${ }^{[22]}$ were inserted in PEM films to obtain efficient bactericidal coatings. Chitosan based PEM films were demonstrated to be antibacterial against Escherichia coli and Enterococcus faecalis. ${ }^{[16,23,24]}$ Antibiotics, like gentamicin, have been inserted in hydrolysable ${ }^{[25]}$ or crosslinked PEM films ${ }^{[26]}$ to be later released. Despite of an improvement of the antibacterial activity of the films, the use of antibiotics or silver particles have serious drawbacks because of their limited efficiency, their toxicity or their role in the emergence of multi-resisting pathogens. ${ }^{[27,28]}$

Natural antimicrobial peptides (AMPs), secreted by numerous living organisms against pathogens, gain increased attention due to their broad spectrum of antimicrobial activity and their low cytotoxicity ${ }^{[12]}$. They predominantly cause disruption of the membrane integrity of pathogen agents and thus unlikely initiate the development of resistance. ${ }^{[12]}$ Positively charged AMPs were already used as a part of the PEM architecture to obtain antibacterial effect by contact ${ }^{[29]}$ or by release. ${ }^{[26,30]}$ Guyomard et al. succeeded in embedding in PEM films a complex of poor water soluble AMPs and amphiphilic polyelectrolytes. They obtained antibacterial activity against Gram-positive bacteria. ${ }^{[31]}$ Active PEM films with embedded antifungal peptides were also reported. ${ }^{[32,33]}$ Yet, it would be of high interest to design coatings bearing both antibacterial and antifungal properties. Up to now, only few systems share both properties. They are mainly based on silver coating ${ }^{[34]}$ or quaternary ammonium cationic molecules as surfactant, ${ }^{[35]}$ synthetic polymer ${ }^{[36]}$ or silane. ${ }^{[37]}$ been reported so far. To achieve this goal, we used bovine cateslytin (CTL), a Chromogranin A (CGA) derived peptide, an endogenous protein, secreted with its numerous natural derived peptides by nervous, endocrine and immune cells during infection ${ }^{[38]}$ acting in the innate 
immunity system ${ }^{[39]}$. CTL, an AMP corresponding to CGA344-358, acts in the micromolar

110 range with a wide spectrum of antimicrobial activities against Gram-positive bacteria, yeasts and filamentous fungi, without cytotoxic effect on mammalian cells. ${ }^{[40,41]}$ Moreover, it is very stable against bacterial proteases. ${ }^{[42]}$ We used polysaccharide multilayer films based on CTLC-functionalized hyaluronic acid as polyanion and chitosan as polycation, (HA-CTL-C/CHI), that were deposited on a planar surface with the aim of designing a self-defensive coating

115 against both bacteria and yeasts (Scheme 1). A cystein residue (C) was added at the Cterminal end of the CTL sequence to allow its grafting to HA. HA and CHI are biodegradable by enzymatic hydrolysis with hyaluronidase ${ }^{[43]}$ and chitosanase ${ }^{[44]}$ respectively. Both polysaccharides are already widely used in biomedical applications due to their interesting intrinsic properties. ${ }^{[45,46]}$ The ability of Staphylococcus, ${ }^{[47]}$ Candida species ${ }^{[48]}$ and M. luteus

120 to degrade HA, by producing hyaluronidase, allows the CTL-C to be released from PEM films only in the presence of the pathogens. Release of antibacterial compounds (AMPs or classical antibiotics) are usually obtained by passive diffusion from the films at physiological $\mathrm{pH}^{[31,32]}$ or by $\mathrm{pH}$-induced degradation of the films ${ }^{[25,30]}$. Pavlukhina et al. reported the release of antimicrobial agents using $\mathrm{pH}$ variations associated with growth of bacteria as an internal trigger to release. ${ }^{[26]}$ This coating can thus be named as self-defensive as it is related to a local change of the environment of the coating due to the pathogens themselves. This was the first system developed based on this idea. We developed herein a new self-defensive coating where the release of the antimicrobial peptide is triggered by enzymatic degradation of the film due to the pathogens themselves. Polysaccharides adsorbed mass was determined by Surface Plasmon Resonance (SPR). The buildup and the topography of the films were characterized by Atomic Force Microscopy (AFM). Antibacterial and antifungal activities of HA-CTL-C in solution and HA-CTL-C/CHI films were tested against two strains Grampositive bacteria, i.e. S. aureus and M. luteus and one strain of yeast strain C. albicans, 
Submitted to

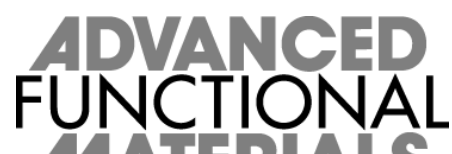

respectively, by using microdilution assays. ${ }^{[49]}$ Confocal laser scanning microscopy (CLSM)

135 allowed following the penetration of the fluorescently labeled HA ${ }^{\text {FITC }}$-CTL-C, diluted in solution or embedded in a PEM film, into the cell membrane of $C$. albicans. Finally, the cytotoxicity of HA-CTL-C/CHI films was tested through Human gingival fibroblasts (HGFs) viability.

\section{Result and discussion}

\subsection{Physical-chemical characterization of HA-CTL-C/CHI films}

CTL-C peptide was covalently coupled to HA in two steps using successively the carbodiimide chemistry to graft maleimide functions on HA and the thiol-maleimide coupling reaction to graft CTL-C on the modified HA. Synthetic procedures of CTL-C peptide and its conjugation to HA are described in Supporting Information (SI). After dialysis and freeze-

145 drying, a coupling ratio of $5 \%$ was determined by ${ }^{1} \mathrm{H}-\mathrm{NMR}$, corresponding to the grafting of approximately 5 CTL-C peptides for 100 HA dimer units (Figure 1a). The antimicrobial and antifungal activities of CTL and modified CTL were tested in solution against two bacterial strains M. luteus and S. aureus (ATCC 25923) and a yeast C. albicans. Minimal inhibitory concentration (MIC) in peptide of CTL, CTL-C and HA-CTL-C were determined using bacterial and fungal assays described in SI. CTL-C remains antimicrobial at micromolar concentration $(<100 \mu \mathrm{M})$ and displays an even better activity against $M$. luteus compared to the cystein free CTL peptide. In comparison with the non-grafted CTL-C peptide, MIC value of HA-CTL-C increases from 35 to $45 \mu \mathrm{M}$ for $S$. aureus and from 20 to $25 \mu \mathrm{M}$ for $C$. albicans (Table 1). In the case of M. luteus, the MIC of HA-CTL-C $(5 \mu \mathrm{M})$ is five times higher than that of free CTL-C $(1 \mu \mathrm{M})$. In spite of this decrease in efficiency, the CTL-C peptide covalently linked to HA polymer can still be considered as antimicrobial, acting in the micromolar range. The buildup of HA-CTL-C/CHI film was monitored by SPR. A linear increase of the mass adsorbed is observed at each deposited layer of polysaccharide indicating 
Submitted to

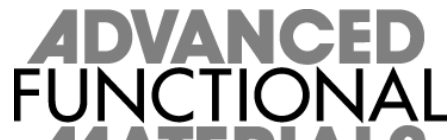

the buildup of the film (Figure 1b). We investigated the topography and the roughness of HA-

CTL-C/CHI films at different numbers of deposition steps by means of AFM in dry state

(Figure S-1 in SI). It was difficult to obtain good quality AFM images in the wet state due to the viscoelasticity of the films as we found for HA/CHI films in our previous work. ${ }^{[50]} \mathrm{AFM}$ imaging allows measuring film thickness after scratching. Table S-1 in SI summarizes the thicknesses and roughnesses measured by AFM. With 5 bilayers, the surface is already entirely covered with a $5 \mathrm{~nm}$ thick film with a roughness of $1.6 \mathrm{~nm}$. As the buildup process goes on, the film thickness increases up to $52 \mathrm{~nm}$ at 30 bilayers. The film grows linearly up to 30 bilayers (Figure S-2 in SI) and the film roughness increases up to $16.5 \mathrm{~nm}$ (for 30 pairs of layers).

\subsection{Bacterial and fungal assays of HA-CTL-C/CHI films}

170 After characterization of HA-CTL-C/CHI multilayers buildup, the antibacterial and antifungal activities of the functionalized films were evaluated against two strains of bacteria M. luteus and S. aureus and one of yeast strain C. albicans, respectively. The influence of the number of embedded functionalized layers was studied by monitoring pathogen growth for different films with increasing number of HA-CTL-C/CHI bilayers. To this aim, PEI-(HA/CHI)15-n-

175 (HA-CTL-C/CHI)n films, with $n=0,5,10$ and 15, and PEI-(HA-CTL-C/CHI) 30 films were built. Pathogens were incubated for $24 \mathrm{~h}$ in contact with HA-CTL-C/CHI films at $37^{\circ} \mathrm{C}$ for bacteria strains and at $30^{\circ} \mathrm{C}$ for $C$. albicans. For each pathogen, the microbial growth was measured at different times $(1 \mathrm{~h}, 4 \mathrm{~h}, 6 \mathrm{~h}$ and $24 \mathrm{~h})$ by determination of the optical density at $620 \mathrm{~nm}\left(\mathrm{OD}_{620}\right)$ of the bacterial suspension in contact with the film. The data were normalized to $\mathrm{OD}_{620}$ value obtained in similar conditions in the absence of films and are expressed as a percentage of growth (Figure 2a-c). For each tested pathogen, we observed that by increasing the number of HA-CTL-C/CHI bilayers the normalized microbial growth decreases. An important decrease of microbial growth is obtained for at least 5 bilayers for M. luteus and $C$. 
Submitted to

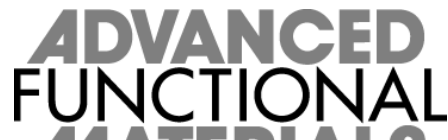

albicans and 15 bilayers for S. aureus. After $6 \mathrm{~h}$ of incubation, at least $70 \%$ of inhibition is

obtained with 15 bilayers for all tested pathogens. After $24 \mathrm{~h}$ of incubation, the growth of $M$. luteus, C. albicans and S. aureus are fully inhibited with 5, 15 and 30 HA-CTL-C/CHI bilayers, respectively. These results are in agreement with the MIC values of HA-CTL-C in solution (Table 1) that follow the same trend towards the different pathogens. In order to check if the films can be reused several times as antimicrobial coatings, the growth of the three pathogens was monitored when incubated for $24 \mathrm{~h}$ in contact with reused PEI-(HACTL-C/CHI) ${ }_{15}$ films for M. luteus and C. albicans and PEI-(HA-CTL-C/CHI) $)_{30}$ film for $S$. aureus. To this aim, a fresh pathogen suspension was brought in contact with the functionalized film. After an incubation of $24 \mathrm{~h}$, the supernatant was withdrawn and replaced by a fresh pathogen suspension. After each withdrawal, the $\mathrm{OD}_{620}$ of the supernatant was measured to determine pathogen growth after $24 \mathrm{~h}$ of incubation. When $M$. luteus and $C$. albicans suspensions in contact with (HA-CTL-C/CHI) 15 film are renewed every $24 \mathrm{~h}$, a complete inhibition was observed at least for two and three cycles of use respectively. A significant decrease in efficiency of (HA-CTL-C/CHI) 15 film is detectable after the following renewal of pathogens suspension (Figure 2d). S. aureus growth is only inhibited by $40 \%$ for the second use of the (HA-CTL-C/CHI) ${ }_{30}$ film and becomes fully inefficient in the third cycle. In parallel, the supernatants withdrawn were incubated with fresh pathogen suspensions for $24 \mathrm{~h}$ and the $\mathrm{OD}_{620}$ was also measured (Figure S-3 in SI). No inhibition of growth was observed showing that there is no or a weak amount (quite less than the MIC) of CTL-C released in solution.

\subsection{Mechanism of pathogen growth inhibition of HA-CTL-C/CHI}

To clarify the mechanism of HA-CTL-C inhibition, we synthesized fluorescently labelled HA $^{\text {FITC }}$-CTL-C and HA $^{\text {FITC }}$ to analyze the films after contact with the pathogens. S. aureus and $C$. albicans are known to secrete hyaluronidase, a class of enzymes able to hydrolyze 
Submitted to

HA. ${ }^{[47,48]}$ The cutting of one constitutive partner of the film should lead to its degradation as

210 it was observed by Etienne et al. ${ }^{[51]}$ We were then interested in imaging PEI-(HA $\left.{ }^{\text {FITC } / C H I ~}\right)_{15}$ films, by CLSM, before and after $24 \mathrm{~h}$ of contact with the pathogens. The three of pathogens induce the degradation of HA/CHI films with, however, some differences in the resulting film morphologies (Figure 3). After $24 \mathrm{~h}$ of incubation with $S$. aureus, $\mathrm{HA}^{\mathrm{FITC}} / \mathrm{CHI}$ films were almost totally degraded (Figure 3a). The film appears inhomogeneous with fluorescent dots

215 after incubation with M. luteus (Figure 3b). C. albicans induces the formation of honeycombs in the film due to the degradation of HA (Figure 3c). Degradation of HA should release CTL$\mathrm{C}$ in the supernatant and promote the contact between CTL-C peptides and the pathogens. To check this hypothesis, we built hyaluronidase resistant films functionalized by CTL-C. CTLC grafted on poly(allylamine hydrochloride) was thus synthesized and used to build poly(acrylic acid)/CTL-C functionalized poly(allylamine hydrochloride) (PAA/PAH-CTL-C) film. After $24 \mathrm{~h}$ of incubation, (PAA/PAH-CTL-C) ${ }_{15}$ films show no inhibition against $C$. albicans (data not shown). This emphasizes the fact that the antimicrobial activity of the HACTL-C/CHI film is due to its degradation by the pathogens. This property renders the film specifically active in the presence of hyaluronidase secreted by the pathogens. Pathogens thus initiate their own death when brought in contact with the HA-CTL-C/CHI film. Even though the film is degraded with time in the presence of pathogens, it can be reused at least two and three times without losing its activity against M. luteus and C. albicans.

Using fluorescently labelled CTL-C, a previous study showed that the peptides penetrate into cell membranes and accumulate inside yeasts. ${ }^{[40,41]}$ The interactions of HA ${ }^{\text {FITC }}$-CTL-C and HA $^{\text {FITC }}$ with $C$. albicans was thus studied when solubilized in solution or embedded in multilayer films. After $45 \mathrm{~min}$ of incubation at $30^{\circ} \mathrm{C}$ with $\mathrm{HA}^{\mathrm{FITC}}$ or $\mathrm{HA}^{\mathrm{FITC}}-\mathrm{CTL}-\mathrm{C}$ in solution, $C$. albicans were observed by CLSM. The fluorescent HA ${ }^{\text {FITC }}$-CTL-C was detectable in cytoplasm without inducing cell lysis (Figure 4a). On the contrary, HA ${ }^{\text {FITC }}$ is clearly 
Submitted to 14 A

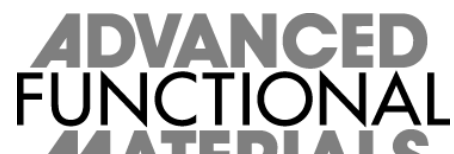

observed all around the yeast cells, stacking probably on the membranes and leading to a

235 honeycomb structure (Figure 4b). This suggests that CTL-C can cross the cell membrane, even when it is coupled to HA, leading to an accumulation of HA inside the cytoplasm. To image them by CLSM, the films were treated by paraformaldehyde (PFA) to fix the pathogen in contact. This treatment was first applied on the films to evaluate its effect. PFA treatment induces no change in the case of $\mathrm{HA}^{\mathrm{FITC}} / \mathrm{CHI}$ films in contrary to $\mathrm{HA}^{\mathrm{FITC}}$-CTL-C/CHI films

240 (Figure S-4 in SI) where heterogeneities appear. C. albicans were incubated for $45 \mathrm{~min}$ at $30^{\circ} \mathrm{C}$ in contact with PEI-(HA $\left.{ }^{\text {FITC }}-\mathrm{CTL}-\mathrm{C} / \mathrm{CHI}\right)_{15}$ film and then observed by CLSM. Among the heterogeneities due to PFA treatment, a strong green fluorescence is observed mainly inside the yeast (Figure 4c). In the case of $\mathrm{HA}^{\mathrm{FITC}} / \mathrm{CHI}$ films, a little fluorescence is localized inside the yeasts and only few of them are strongly fluorescent (Figure 4d). In spite of its

245 insertion into the PEM films, CTL-C allows the penetration of HA ${ }^{\text {FITC }}$-CTL-C inside the yeasts explaining the activity of the films.

\subsection{Biocompatibility tests of HA-CTL-C/CHI films}

Finally, it is important to ensure that the film is not cytotoxic to healthy wound healing cells.

250 Fibroblasts are one of the first anchorage-dependent cells to come at an implant surface during the wound healing process. The viability of human gingival fibroblasts (HGFs) cultivated on PEI-(HA-CTL-C/CHI $)_{15}$ films, compared to PEI-(HA/CHI) ${ }_{15}$ films and glass substrate, has been evaluated through their mitochondrial activity, monitored by Alamar blue $^{\mathrm{TM}}$ assays. Already after one day, the metabolic cell activity measured on HA-CTL$\mathrm{C} / \mathrm{CHI}$ films is lower compared to HA/CHI films and non-coated glass substrate (Figure 5a). The good biocompatibility of HA/CHI films towards HGFs, mediated via CD44 receptor, was already reported in our previous work. ${ }^{[50]}$ After 7 days of culture, the number of viable HGFs 
Submitted to

on HA-CTL-C/CHI films represents $25 \%$ of viable HGFs on HA/CHI films. The functionalization of HA by CTL-C peptide induces a lower adhesion of HGFs which seems to slow down the proliferation of cells. Knowing that HA-CTL-C in solution at $100 \mu \mathrm{M}$ did not show any cytotoxicity (data not shown), such behavior would suggest that the multilayers are not cytotoxic. To discriminate between cytotoxic or low initial adhesion properties of HACTL-C/CHI, we performed two experiments. First after $24 \mathrm{~h}$ of contact, suspended cells harvested from HA-CTL-C/CHI film supernatant were passed to fresh culture plates. After $24 \mathrm{~h}$ of culture, many cells readily attached and spread as fresh cells. Second, we analyzed the biocompatibility of films by a complementary assay based on cell spreading via cytoskeleton arrangement when the cells are seeded on a glass substrate half coated by (HA-CTL$\mathrm{C} / \mathrm{CHI})_{15}$. After $24 \mathrm{~h}$, HGFs adhere on the glass substrate (Figure 5b, zone II), but to a lesser degree on (HA-CTL-C/CHI) 15 film (Figure 5b, zone I). After $24 \mathrm{~h}$ of culture, a confluent layer with a typical fibroblastic cell shape and with polymerized F-actin fibers is observed on the glass substrate (Figure S-5a in SI). On the HA-CTL-C/CHI film, cells appear less elongated and have a peripheral actin distribution (Figure S-5b in SI). This indicates that (HA-CTL-C/CHI) 15 films are not cytotoxic but seem rather anti-adherent towards HGFs. It is know that persistent excessive functions of fibroblasts have been linked to detrimental fibrous tissue formation which may cause implant failure. The present results of decreased fibroblast adhesion on functionalized substrate with HA-CTL-C/CHI films shows promise for implant applications.

\section{Conclusions}

In conclusion, we designed a new surface coating based on polysaccharide multilayer films

containing a functionalized HA with $5 \%$ of CTL-C, a peptide possessing both antibacterial and antifungal properties. Antimicrobial properties of CTL-C were preserved when grafted on HA either in solution or when embedded into PEM films. After $24 \mathrm{~h}$ of incubation, HA-CTL- 
Submitted to

$\mathrm{C} / \mathrm{CHI}$ films fully inhibit the development of S. aureus and C. albicans, which are common and virulent pathogens agents encountered in care-associated diseases. The presence of CTL$\mathrm{C}$ peptides on HA allows the penetration of the modified polysaccharide inside C. albicans after 45 min of contact. The secretion of hyaluronidase by all tested pathogens seems to be responsible for HA-CTL-C release from the film and for its activity. The film can keep its activity during 3 cycles of use against fresh incubated $C$. albicans suspension. Furthermore, the limited fibroblasts adhesion, without cytotoxicity, on HA-CTL-C/CHI films highlights a medically relevant application to prevent infections on catheters or tracheal tubes where fibrous tissue encapsulation is undesirable.

\section{Experimental}

Polysaccharide solutions. Chitosan (CHI, PROTASAN Ultrapure Chitosan CL213, 260000 g/mol, DA $83 \%$ ) was purchased by Novamatrix (Sandvika, Norway). Dried Sodium Hyaluronate (HA, $420000 \mathrm{~g} / \mathrm{mol}$ ) was purchased by Lifecore (Chaska, USA). Poly(ethylene imine) (PEI, $60000 \mathrm{~g} / \mathrm{mol}, 50 \%$ in water), sodium chloride, sodium dodecyl sulfate (SDS), $\mathrm{HCl}$ and $\mathrm{NaOH}$ were purchased by Sigma-Aldrich (Quentin-Fallavier, France). All products were used without further purification. $150 \mathrm{mM} \mathrm{NaCl}$ solution was prepared with Ultrapure Milli-Q ${ }^{\circledR}$ water having a resistivity of $18.2 \mathrm{M} \Omega . \mathrm{cm}$. CHI and HA solutions were prepared at $0.3 \mathrm{mg} / \mathrm{mL}$ in $150 \mathrm{mM} \mathrm{NaCl}$ adjusted at $\mathrm{pH} 4$ with $\mathrm{NaOH}$ or $\mathrm{HCl}$ solutions. HA-CTL-C and $\mathrm{HA}^{\text {FITC }}$-CTL-C solutions were prepared at $0.2 \mathrm{mg} / \mathrm{mL}$ and $0.1 \mathrm{mg} / \mathrm{mL}$, respectively. PEI solution was prepared at $0.5 \mathrm{mg} / \mathrm{mL}$ in $150 \mathrm{mM} \mathrm{NaCl}$ solution adjusted at $\mathrm{pH} 7.5$ with $\mathrm{NaOH}$ or $\mathrm{HCl}$ solutions.

Film buildup. Before PEM buildup, glass coverslips $(\varnothing=14$ mm; VWR, Strasbourg,

305 France) were cleaned in a SDS solution at $0.01 \mathrm{M}$, ultrasonicated for $5 \mathrm{~min}$ and then submitted to a hot $0.1 \mathrm{M} \mathrm{HCl}$ solution for $10 \mathrm{~min}$ and finally rinsed with ultrapure Milli-Q ${ }^{\circledR}$ water. The precursor PEI layer and $\mathrm{CHI} / \mathrm{HA}$ films were deposited using an automated 
Submitted to

FUNCTIONAL

spraying device described in a previous work ${ }^{[50]}$. CHI/HA-CTL-C and CHI/HA ${ }^{\text {FITC }}$-CTL-C films have been prepared in 24-well plates on PEI precoated glass substrates. $300 \mu \mathrm{L}$ of the polycation solution were deposited for 5 min on glass coverslips followed by a rinsing step $(500 \mu \mathrm{L})$ with ultra Milli Q water. Then, $300 \mu \mathrm{L}$ of polyanion solution were deposited for 5 min followed by a rinsing step $(500 \mu \mathrm{L})$ with ultra Milli Q water. To test the antimicrobial activity of PEM films versus the number of HA-CTL-C layers, PEI-[HA/CHI $]_{15-n}[\mathrm{HA}-\mathrm{CTL}-$ $\mathrm{C} / \mathrm{CHI}]_{n}$ with $n$ equal to $0,5,10$ and 15 and PEI-[HA-CTL-C/CHI $]_{30}$ films were built.

Surface Plasmon Resonance. Surface plasmon resonance (SPR $)^{[53,54]}$ as some other detection techniques (optical waveguide lightmode spectroscopy, quartz crystal microbalance), provides a label-free, in situ method to monitor the buildup of e.g. a polymer film on a solid surface. When a beam of light passes from a material of refractive index, $n_{1}$, into a material with a lower refractive index, $n_{2}$, some light is reflected from the interface. When the angle of incidence of the light, $\theta$, on the interface is greater than $\theta_{T I R}=$ $\arcsin \left(n_{2} / n_{1}\right)$, the light is completely reflected (total internal reflection). In the case of the SPR instrument used here (SPR Navi ${ }^{\mathrm{TM}}$ 200, Bionavis, Finland), the most refractive medium is a BK7-glass prism. Because the bottom surface of the prism is coated with a thin film of a noble metal (gold), this reflection is not total; some of the light is 'lost' into the metallic film.

325 There then exists a second angle, $\theta_{\mathrm{SPR}}>\theta_{\mathrm{TIR}}$, at which the intensity of the reflected light goes through a minimum. In addition, an evanescent electrical field travels for a short distance into the medium (e.g. film) from the metallic film. The probing distance reaches generally a few hundreds of nm depending on the refractive index of the probed medium and $\theta_{\mathrm{SPR}}$ is sensitive to the optical characteristics of the deposited film. The reflection curves, i.e. the variation of the intensity of the reflected light with $\theta$, corresponding to the successive polymer deposition steps have been analyzed with a home-made software based on Maxwell's equations. The parameters involved are the refractive indices of the prism, the chromium and gold layers, the 
Submitted to

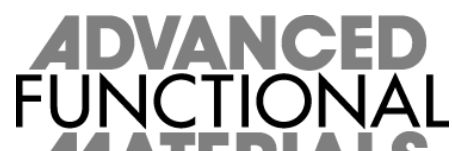

polymer film $\left(n_{\mathrm{film}}\right)$ and the buffer solution $\left(n_{\mathrm{sol}}\right)$, as well as the thickness of the chromium and gold layers and of the film $\left(d_{\text {film }}\right)$. From $n_{\text {film }}, n_{\text {sol }}$ and $d_{\text {film, }}$, we derive the mass of film per unit area:

$$
m=\frac{\left(n_{\text {film }}-n_{\text {sol }}\right) d_{\text {film }}}{\mathrm{d} n / \mathrm{d} c}
$$

where $\mathrm{d} n / \mathrm{d} c$ is the change in refractive index with concentration and is equal to $0.197 \mathrm{~cm}^{3} / \mathrm{g}$ for polyelectrolytes ${ }^{[55]}$. The SPR experiment was performed under a continuous flow rate of $100 \mu \mathrm{L} / \mathrm{min}$ of $150 \mathrm{mM} \mathrm{NaCl}$ solution adjusted at $\mathrm{pH}$ 4. The time of deposition and of rinsing of polyelectrolytes was fixed at $5 \mathrm{~min}$.

Atomic Force Microscopy (AFM). Atomic force microscopy (AFM) images were obtained in contact mode in dry state with the Nanoscope IV from Veeco (Santa Barbara, CA). The images were carried out with silicon nitride cantilevers, spring constant $0.03 \mathrm{~N} / \mathrm{m}$ (model MSCTAUHW, Veeco, CA). Several scans were performed over a given surface area.

345 These scans had to give reproducible images to ascertain that there is no sample damage induced by the tip. Deflection and height mode images are scanned simultaneously at a fixed scan rate $(2 \mathrm{~Hz})$ with a resolution of $512 \times 512$ pixels. Data evaluation was performed with the NanoScope software version 5.31r1 (Digital Instruments, Veeco). The buildup of the film was made on glass substrate and the film thickness was measured by using the "scratch" method. Profilometric section analyses of a scratched film allowed us to determine precisely the quality of the film and its thickness over the scanned area. The scratches were achieved with a plastic cone tip and were always imaged perpendicular to the fast scan axis. The profiles correspond to a cross section along this axis. The mean thickness of the scratched film was determined by measuring the thickness at least on three areas. 
Submitted to

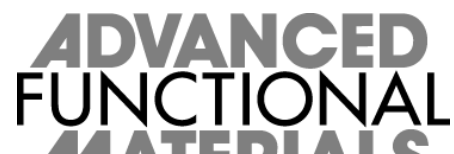

14 A E R A

immersion objective and a $0.43 \mu \mathrm{m}$ z-section interval. FITC fluorescence was detected upon excitation at $488 \mathrm{~nm}$, through a cut-off dichroic mirror and an emission bandpass filter of 505-530 nm (green).

Bacterial and fungal growth. To determine the antibacterial activity, microdilution assay was used on two bacterial strains M. luteus (A270) and S. aureus (ATCC25923). The antifungal activity was tested against one yeast strain $C$. albicans. Bacteria were precultured aerobically in Mueller-Hinton (MH) broth (Merck, Darmstadt, Germany) with agitation at $37^{\circ} \mathrm{C}$ for 18 h. C. albicans preculture was carried out on a Sabouraud broth (SB) medium (BioMérieux S.A., Marcy l'Etoile, France) with agitation at $30^{\circ} \mathrm{C}$ for $24 \mathrm{~h}$. The antimicrobial activity was tested using a mid-logarithmic-phase culture of bacteria or yeast with an initial optical density at $620 \mathrm{~nm}\left(\mathrm{OD}_{620}\right)$ of 0.001 . For the tests performed in solution, aqueous solutions of CTL, CTL-C and HA-CTL-C were prepared in bacterial or yeast medium. Aliquots of CTL-C or HA-CTL-C $(10 \mu \mathrm{L})$ were incubated in 96-well microplates (Falcon,

Becton Dickinson, USA) with $90 \mu \mathrm{L}$ of bacteria or yeast at final concentrations of $100 \mu \mathrm{M}$ to $2 \mu \mathrm{M}$ of peptide. After $24 \mathrm{~h}$ of incubation at $37^{\circ} \mathrm{C}$ under gentle stirring, the $\mathrm{OD}_{620}$ of the $96-$ well plate was measured by a microplate reader. ${ }^{[56,57]} \mathrm{MIC}_{100}$, the minimal inhibitory concentration, is the lowest concentration that is able to completely inhibit the growth of bacterial or fungi after $24 \mathrm{~h}$ of contact. To test the antibacterial and antifungal properties of 375 the multilayer films, PEI-(HA/CHI) ${ }_{15-\mathrm{n}}-(\mathrm{HA}-\mathrm{CTL}-\mathrm{C} / \mathrm{CHI})_{\mathrm{n}}$ with $n=0,5,10$ and 15 and PEI(HA-CTL-C/CHI) $)_{30}$ films were prepared. $400 \mu \mathrm{L}$ of a mid-logarithmic-phase culture of bacteria or yeast with $\mathrm{OD}_{620}$ of 0.001 were placed in 24 -well plate containing multilayer films. For each tested film, $100 \mu \mathrm{L}$ of the supernatant was taken to measure its $\mathrm{OD}_{620}$ by a microplate reader. The withdrawn volume was compensated with the appropriated fresh bacteria or yeast solution of the same measured $\mathrm{OD}_{620}$. Intermittent controls were performed by inoculating the culture medium on $\mathrm{MH}$ (resp. SB) agar plates by spreading method and 
Submitted to

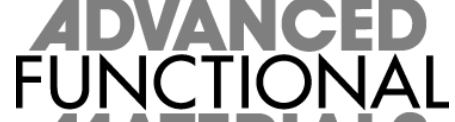

counting colonies for verification at different steps. Several controls were used: a fresh medium without inoculation of pathogens was used to ensure sterility, a mixture of Tetracycline $(10 \mu \mathrm{g} / \mathrm{mL})$ and Cefotaxime $(0.1 \mu \mathrm{g} / \mathrm{mL})$ was used as positive control $(90 \mu \mathrm{L}$ of culture and $10 \mu \mathrm{L}$ of antibiotics) and a fresh inoculated culture medium without any addition was taken as negative control. For the bacterial and yeast quantification, a conversion factor was devised to convert OD into bacterial and yeast counting, respectively. Briefly, OD of fresh bacteria (resp. yeast) culture was measured at $620 \mathrm{~nm}$ and was plated to MH (resp. SB) agar for $24 \mathrm{~h}$ at $37^{\circ} \mathrm{C}$ (resp. $30^{\circ} \mathrm{C}$ ). Colony count was performed and plotted versus the $\mathrm{OD}_{620}$ and the slope of the linear curve was taken as conversion factor. Pathogen quantification (colony forming unit (CFU) per $\mathrm{mL}$ ) was performed at time zero and then at each hour for $6 \mathrm{~h}$ and then finally at $24 \mathrm{~h}$. For quantification, conversion factors were determined for each strain used separately. ${ }^{[58]}$ Each assay was performed in triplicate and the experiments were repeated at least three times. The normalized growth of pathogens (in \%) was estimated by comparing the $\mathrm{OD}_{620}$ values in the presence of multilayer films and the positive and the negative controls. The $\mathrm{OD}_{620}$ value of control cultures growing in the absence of films and antibiotics was taken as $100 \%$ growth (negative control) and the $\mathrm{OD}_{620}$ value of cultures growing in the presence of antibiotics (Tetracycline and Cefotaxime) was taken as $0 \%$ growth (positive control). To this aim, the following equation was used:

$$
\text { Normalized pathogen growth }(\%)=\frac{\left(O D_{620, \text { sample }}-O D_{620, \text { positivecontrol }}\right)}{\left(O D_{620, \text { negativecontrol }}-O D_{620, \text { positivecontrol }}\right)} \times 100
$$

To follow the interaction of fluorescently labeled HA ${ }^{\text {FITC }}$-CTL-C in solution and HA ${ }^{\text {FITC }}$ CTL-C/CHI films with C. albicans, CLSM was used based on a protocol previously described with few modifications. ${ }^{[59]}$ Briefly, for experiments done with $\mathrm{HA}^{\text {FITC }}-\mathrm{CTL}-\mathrm{C}$ in solution, poly-L-Lysine coated microscopic slides were covered with fresh medium containing $C$. albicans $\left(\mathrm{OD}_{620}=0.001\right)$ in $\mathrm{SB}$ culture medium and incubated for $24 \mathrm{~h}$ at $30^{\circ} \mathrm{C}$ without 
Submitted to

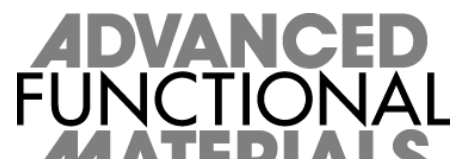

agitation. The medium was then removed and replaced by $50 \mu \mathrm{M}$ (in peptide) of $\mathrm{HA}^{\mathrm{FITC}}$ CTL-C. After an incubation period of $45 \mathrm{~min}$, the slides were washed with fresh culture medium and subsequently treated for 30 min with $4 \%$ paraformaldehyde in phosphate buffer saline (PBS) at $\mathrm{pH}$ 7.3. After several rinsing steps with PBS, slides were covered with Moviol 4-88 (Aldrich, Steinheim, Germany). For experiments performed with HA ${ }^{\text {FITC }}$-CTL-C/CHI, fresh $C$. albicans medium, previously incubated at $\mathrm{OD}_{620}=0.001$ in $\mathrm{SB}$ culture medium for $24 \mathrm{~h}$ at $30^{\circ} \mathrm{C}$ without agitation, was put in contact with PEI-(HA $\left.{ }^{\mathrm{FITC}}-\mathrm{CTL}-\mathrm{C} / \mathrm{CHI}\right)_{15}$ films for 45 min at $30^{\circ} \mathrm{C}$ without agitation. $\mathrm{HA}^{\mathrm{FITC}}$ in solution and $\mathrm{HA}^{\mathrm{FITC}} / \mathrm{CHI}$ films were used as control. C. albicans were subjected to optical serial sectioning $(0.2-0.3 \mu \mathrm{m})$ to produce images in the $x-y$ plane. Each optical section was scanned several times to obtain an average image. Images were recorded digitally in a $768 \times 576$ pixel format.

Human gingival fibroblasts viability assays. The biocompatibility of films was tested using human gingival fibroblasts (HGFs). HGFs were extracted from human gingival connective tissue of healthy individuals according to a protocol approved by the ethics committee for patient protection of CPP Strasbourg Hospitals. Cells were grown in DMEM containing $1 \mathrm{~g} / \mathrm{L}$ of glucose and supplemented with $10 \%$ fetal bovine serum and $100 \mathrm{IU} / \mathrm{mL}$ penicillin-streptomycin (all from Gibco ${ }^{\circledR}$ ). Cells were cultured at $37^{\circ} \mathrm{C}$ in $5 \% \mathrm{CO}_{2}$ in $75 \mathrm{~cm}^{2}$ flasks. HGFs were used between the $6^{\text {th }}$ and the $9^{\text {th }}$ passage. Before cell seeding, glass coverslips $(\varnothing=14 \mathrm{~mm})$ coated with different architectures were irradiated by UV for $15 \mathrm{~min}$.

425 Then HGFs were seeded at $3 \times 10^{4}$ cells per $\mathrm{cm}^{2}$ and cultivated at $37^{\circ} \mathrm{C}$ under a $5 \% \mathrm{CO}_{2}$ humidified atmosphere for different culture times (Day 1, Day 2 and Day 7). Cell viability was assessed by Alamar Blue ${ }^{\mathrm{TM}}$ assay (Biosource International). This assay is based on the reduction of the blue, non-fluorescent resazurin dye to the pink and fluorescent resorufin dye by living cells. ${ }^{[60]}$ The overall conversion rate is proportional to the metabolic activity of 430 living cells. ${ }^{[61]}$ Viability was assessed for different times 1, 2 and 7 days. After rinsing with 
Submitted to

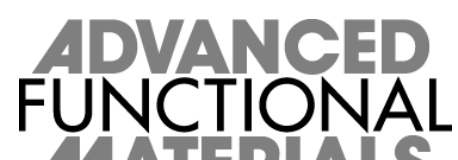

PBS, cells were incubated with $10 \%$ reagent in complete medium for $2 \mathrm{~h}$. After incubation optical density (OD) at $570 \mathrm{~nm}$ and $630 \mathrm{~nm}$ were determined with a microplate reader. The percentage of reduction of Alamar Blue ${ }^{\mathrm{TM}}$ was calculated according to the procedure provided by the manufacturer. The experiments were performed in triplicate. Actin filament staining with tetramethylrhodamine B isothiocyanate coupled phalloidin ${ }^{\circledR}$ (Sigma-Aldrich) and DAPI (Invitrogen) nuclei counterstaining were performed as follows: cells were fixed with $3.7 \%$ paraformaldehyde for $10 \mathrm{~min}$ at $4^{\circ} \mathrm{C}$, permeabilized in $0.25 \%$ Triton X-100 in PBS for 10 min, and blocked in 1\% BSA-PBS for $30 \mathrm{~min}$. Thereafter, cells were incubated for $30 \mathrm{~min}$ at room temperature with $5 \times 10^{-5} \mathrm{mg} / \mathrm{mL} \mathrm{mL}$ phalloidin ${ }^{\circledR}$ followed by nuclear counterstaining

440 with DAPI (50 $\mathrm{ng} / \mathrm{mL})$ incubated for $2 \mathrm{~min}$ at room temperature. Washed slides were mounted on blades with DAKO fluorescent mounting medium and fluorescence distribution was examined by means of an inverse fluorescence microscope (Axiovert, Zeiss).

\section{Acknowledgements}

Aurélie Garnier is acknowledged for technical support. Karim Benmlih, Mathias Lefort and 445 Joseph Hemmerlé are acknowledged for the automated sprayer development. Bernard Guerold is acknowledged for peptide synthesis. Géraldine Koenig is acknowledged for fruitful discussion. G. C. was supported by a "BDI" doctoral fellowship of the Centre National de la Recherche Scientifique and the Région Alsace. L. S. was supported by the grant from Ministère de l'Enseignement Supérieur et de la Recherche (France) and R. A. by the grant from Higher Education Commission (Pakistan) and the faculty of Dentistry of the University of Strasbourg. T.G. was supported by the icFRC foundation. We acknowledge the Pôle Matériaux et Nanosciences d'Alsace (PMNA) ("Jeunes Chercheurs du PMNA 2009" grant), the MICA Carnot (SELF-DECAMP) and the Faculty of Dentistry of the University of Strasbourg for financial contribution. The contributions of the different authors are as follows:

455 G.C. and L.S. performed the physico-chemical characterization of the films, B.S. treated the SPR data, R.A. performed the antimicrobial assays, G.C., A.P. and T.G performed the synthesis of the polymers, R.F. performed the confocal images, A. C. and G.C. performed the biocompatibility tests, H.K. supervised the biocompatibility tests. L.J. supervised the synthesis of functionalized polymers, M-H.M.B. supervised the purification of antimicrobial peptide and the antimicrobial assays, F.B. initiated the project, F.B. and P.S. supervised the work, Y.F., J-C.V., L.J., F.S., P.S., M-H.M.B. and F.B. participated actively in the discussions about the results, G.C., F.B., L.J. and P.S. wrote the paper. Supporting Information is available online from Wiley InterScience or from the author. 


\section{References}

[1] C. von Eiff, B. Jansen, W. Kohnen, K. Becker, Drugs 2005, 65, 179.

[2] J. P. Guggenbichler, O. Assadian, M. Boeswald, A. Kramer, GMS Krankenhaushyg. Interdiszip. 2011, 6, 1.

[3] R. Katneni, S. S. Hedayati, Nat. Clin. Pract. Nephr. 2007, 3, 256.

[4] G. Paniagua-Contreras, T. Sáinz-Espuñes, E. Monroy-Pérez, J. R. RodríguezMoctezuma, D. Arenas-Aranda, E. Negrete-Abascal, S. Vaca, Adv. Microbiol. 2012, 2, 476.

[5] M. M. Harriott, M. C. Noverr, Antimicrob. Agents Chemother. 2009, 53, 3914.

[6] M. E. Shirtliff, B. M. Peters, M. A. Jabra-Rizk, FEMS Microbiol. Lett. 2009, 299, 1.

[7] E. Carlson, Infect. Immun. 1983, 42, 285.

480 [8] S. A. Klotz, B. S. Chasin, B. Powell, N. K. Gaur, P. N. Lipke, Diagn. Microbiol. Infect. Dis. 2007, 59, 401.

[9] G. Ramage, J. P. Martinez, J. L. Lopez-Ribot, Fems Yeast Res. 2006, 6, 979.

[10] A. Lupetti, R. Danesi, M. Campa, M. Del Tacca, S. Kelly, Trends Mol. Med. 2002, 8, 76.

485 [11] I. Banerjee, R. C. Pangule, R. S. Kane, Adv. Mater. 2011, 23, 690.

[12] K. Glinel, P. Thebault, V. Humblot, C. M. Pradier, T. Jouenne, Acta Biomater. 2012, $8,1670$.

[13] G. Decher, Science 1997, 277, 1232.

[14] V. Gribova, R. Auzely-Velty, C. Picart, Chem. Mater. 2012, 24, 854.

$490 \quad$ [15] J. H. Dai, M. L. Bruening, Nano Letters 2002, 2, 497.

[16] J. H. Fu, J. Ji, D. Z. Fan, J. C. Shen, J. Biomed. Mater. Res. Part A 2006, 79A, 665.

[17] Z. Shi, K. G. Neoh, S. P. Zhong, L. Y. Yung, E. T. Kang, W. Wang, J. Biomed. Mater. Res. A 2006, 76, 826.

[18] D. Lee, R. E. Cohen, M. F. Rubner, Langmuir 2005, 21, 9651.

495 [19] Z. Li, D. Lee, X. X. Sheng, R. E. Cohen, M. F. Rubner, Langmuir 2006, 22, 9820.

[20] D. Lee, M. F. Rubner, R. E. Cohen, Chem. Mater. 2005, 17, 1099.

[21] P. M. Nguyen, N. S. Zacharia, E. Verploegen, P. T. Hammond, Chem. Mater. 2007, $19,5524$.

[22] M. Malcher, D. Volodkin, B. Heurtault, P. André, P. Schaaf, H. Möhwald, J.-C.

500 Voegel, A. Sokolowski, V. Ball, F. Boulmedais, B. Frisch, Langmuir 2008, 24, 10209.

[23] J. H. Fu, J. Ji, W. Y. Yuan, J. C. Shen, Biomaterials 2005, 26, 6684.

[24] S. Bratskaya, D. Marinin, F. Simon, A. Synytska, S. Zschoche, H. J. Busscher, D. Jager, H. C. van der Mei, Biomacromolecules 2007, 8, 2960.

[25] H. F. Chuang, R. C. Smith, P. T. Hammond, Biomacromolecules 2008, 9, 1660.

505 [26] S. Pavlukhina, Y. M. Lu, A. Patimetha, M. Libera, S. Sukhishvili, Biomacromolecules 2010, 11, 3448 .

[27] J. Verran, K. Whitehead, Int. J. Artif. Organs 2005, 28, 1138.

[28] K. Bruellhoff, J. Fiedler, M. Moller, J. Groll, R. E. Brenner, Int. J. Artif. Organs 2010, $33,646$.

510 [29] O. Etienne, C. Picart, C. Taddéi, Y. Haikel, J. L. Dimarcq, P. Schaaf, J.-C. Voegel, J. A. Ogier, C. Egles, Antimicrob. Agents Chemother. 2004, 48, 3662. 
Submitted to

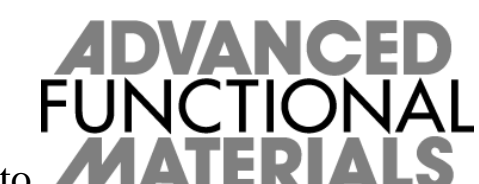

[30] A. Shukla, K. E. Fleming, H. F. Chuang, T. M. Chau, C. R. Loose, G. N. Stephanopoulos, P. T. Hammond, Biomaterials 2010, 31, 2348.

[31] A. Guyomard, E. De, T. Jouenne, J. J. Malandain, G. Muller, K. Glinel, Adv. Funct. Mater 2008, 18, 758.

[32] A. J. Karlsson, R. M. Flessner, S. H. Gellman, D. M. Lynn, S. P. Palecek, Biomacromolecules 2010, 11, 2321.

[33] O. Etienne, C. Gasnier, C. Taddéi, J.-C. Voegel, D. Aunis, P. Schaaf, M.-H. MetzBoutigue, A. L. Bolcato-Bellemin, C. Egles, Biomaterials 2005, 26, 6704.

520 [34] R. Prucek, J. Tucek, M. Kilianova, A. Panacek, L. Kvitek, J. Filip, M. Kolar, K. Tomankova, R. Zboril, Biomaterials 2011, 32, 4704.

[35] D. Botequim, J. Maia, M. M. F. Lino, L. M. F. Lopes, P. N. Simoes, L. M. Ilharco, L. Ferreira, Langmuir 2012, 28, 7646.

[36] F. X. Hu, K. G. Neoh, L. Cen, E. T. Kang, Biotechnol. Bioeng. 2005, 89, 474.

525 [37] J. J. H. Oosterhof, K. J. D. A. Buijssen, H. J. Busscher, B. F. A. M. van der Laan, H. C. van der Mei, Appl. Environ. Microbiol. 2006, 72, 3673.

[38] K. B. Helle, A. Corti, M.-H. Metz-Boutigue, B. Tota, Cell. Mol. Life Sci. 2007, 64, 2863.

[39] D. Zhang, T. Lavaux, A. C. Voegeli, T. Lavigne, V. Castelain, N. Meyer, R. Sapin, D.

530 Aunis, M.-H. Metz-Boutigue, F. Schneider, Clin. Chem. 2008, 54, 1497.

[40] J. Briolat, S. D. Wu, S. K. Mahata, B. Gonthier, D. Bagnard, S. Chasserot-Golaz, K. B. Helle, D. Aunis, M.-H. Metz-Boutigue, Cell. Mol. Life Sci. 2005, 62, 377.

[41] P. Shooshtarizadeh, D. Zhang, J. F. Chich, C. Gasnier, F. Schneider, Y. Haikel, D. Aunis, M.-H. Metz-Boutigue, Regul. Pept. 2010, 165, 102.

535 [42] R. Aslam, M. Atindehou, T. Lavaux, Y. Haikel, F. Schneider, M.-H. Metz-Boutigue, Curr. Med. Chem. 2012, 19, 4115.

[43] E. J. Menzel, C. Farr, Cancer Lett. 1998, 131, 3.

[44] T. Serizawa, M. Yamaguchi, M. Akashi, Macromolecules 2002, 35, 8656.

[45] N. Volpi, J. Schiller, R. Stern, L. Soltes, Curr. Med. Chem. 2009, 16, 1718.

540 [46] R. Riva, H. Ragelle, A. des Rieux, N. Duhem, C. Jerome, V. Preat, Adv. Polym. Sci. 2011, 244, 19.

[47] E. A. Larkin, R. J. Carman, T. Krakauer, B. G. Stiles, Curr. Med. Chem. 2009, 16, 4003.

[48] M. T. Shimizu, N. Q. Almeida, V. Fantinato, C. S. Unterkircher, Mycoses 1996, 39,

161.

[49] CLSI, Methods for dilution antimicrobial susceptibility tests for bacteria that grow aerobically; approved standards 8th version. CLSI document M07-A8, Clinical and laboratory standards institute, Wayne, PA 2009.

[50] G. Cado, H. Kerdjoudj, A. Chassepot, M. Lefort, K. Benmlih, J. Hemmerlé, J.-C. 550 Voegel, L. Jierry, P. Schaaf, Y. Frère, F. Boulmedais, Langmuir 2012, 28, 8470.

[51] O. Etienne, A. Schneider, C. Taddéi, L. Richert, P. Schaaf, J.-C. Voegel, C. Egles, C. Picart, Biomacromolecules 2005, 6, 726.

[52] L. Richert, F. Boulmedais, P. Lavalle, J. Mutterer, E. Ferreux, G. Decher, P. Schaaf, J.-C. Voegel, C. Picart, Biomacromolecules 2004, 5, 284.

555 [53] E. Kretschmann, Z. Physik 1971, 241, 313.

[54] J. Homola, S. S. Yee, G. Gauglitz, Sensor Actuat B-Chem 1999, 54, 3.

[55] X. Arys, A. M. Jonas, B. Laguitton, R. Legras, A. Laschewsky, E. Wischerhoff, Progress in Organic Coatings 1998, 34, 108.

[56] P. Bulet, J. L. Dimarcq, C. Hetru, M. Lagueux, M. Charlet, G. Hegy, A. Van Dorsselaer,

560 J. A. Hoffmann, J. Biol. Chem. 1993, 268, 14893.

[57] M. H. Wu, R. E. W. Hancock, J. Biol. Chem. 1999, 274, 29. 


\section{Submitted to

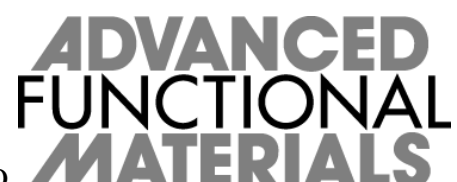

[58] D. Y. Lee, C. M. Huang, T. Nakatsuji, D. Thiboutot, M. Monestier, R. L. Gallo, J. Invest. Dermatol. 2009, 129, S7.

[59] K. Lugardon, S. Chasserot-Golaz, A. E. Kieffer, G. Maget-Dana, G. Nullans, B. Kieffer, 565 D. Aunis, M.-H. Metz-Boutigue, J. Biol. Chem. 2001, 276, 35875.

[60] B. Page, M. Page, C. Noel, Int. J. Oncol. 1993, 3, 473.

[61] S. L. Voytik-Harbin, A. O. Brightman, B. Waisner, C. H. Lamar, S. F. Badylak, In Vitro Cell. Dev. Biol.-Anim. 1998, 34, 239. 


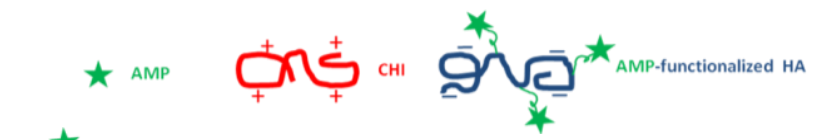

580

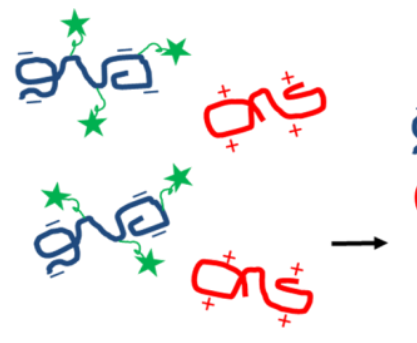

Biomaterials

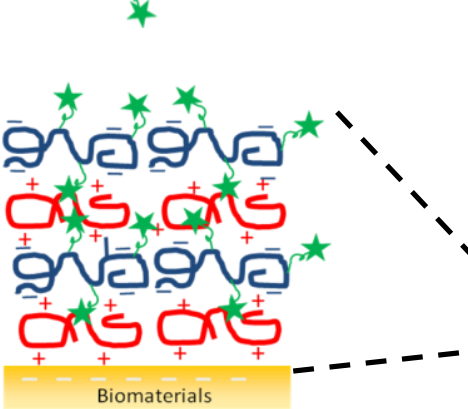

Bacteria

Yeast

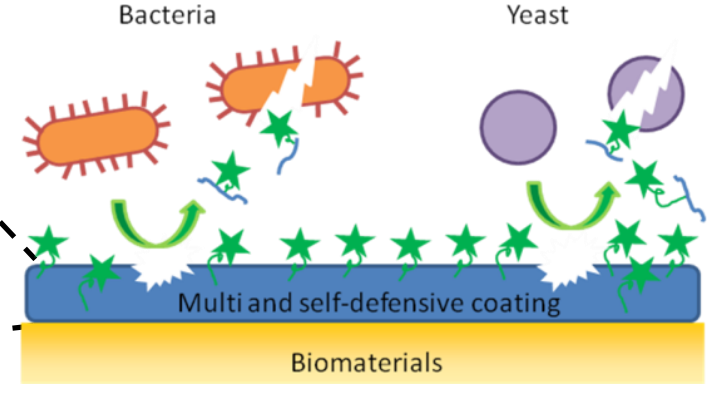

Scheme 1. Schematic representation of CHI/HA multilayers functionalized by an antimicrobial peptide (AMP) and its activity towards bacteria and yeasts based on the degradation of the film.

a

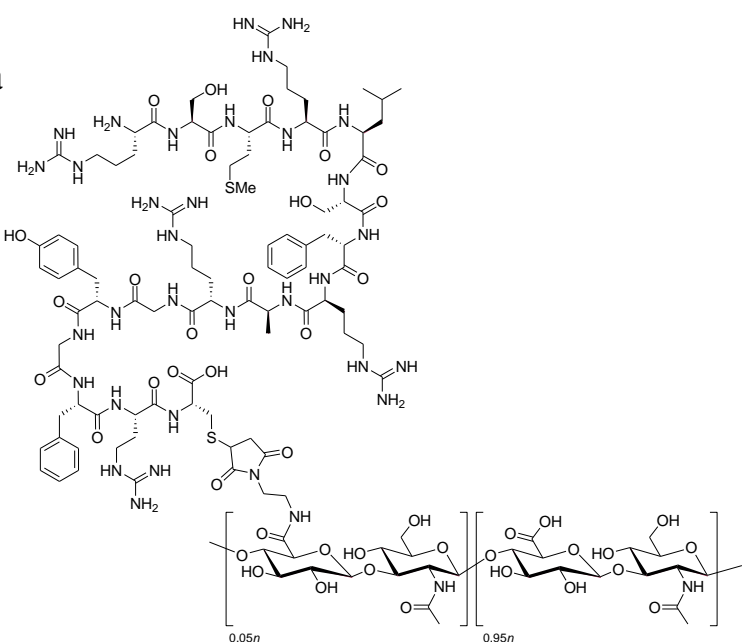

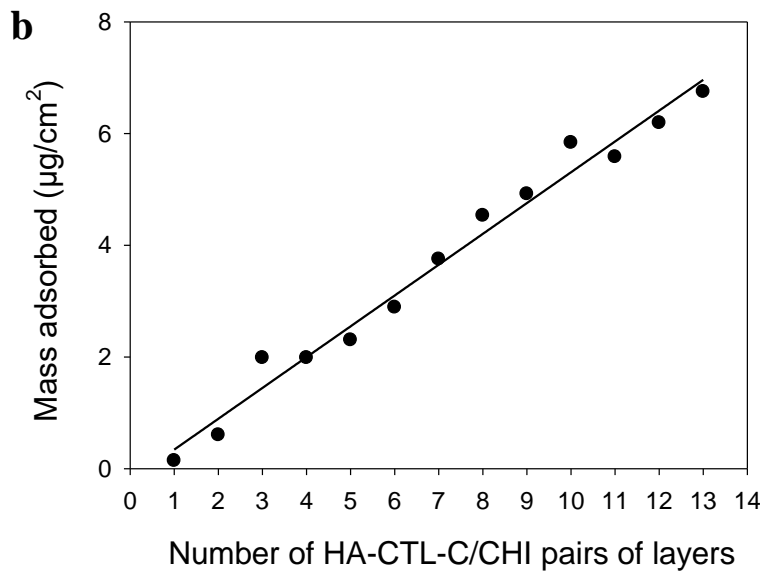

600

Figure 1. (a) Formula of CTL-C functionalized hyaluronic acid, HA-CTL-C, at 5\% in grafting ratio (b) Evolution of the mass adsorbed, measured by SPR, (black disks) for the buildup of PEI-(HA-CTL-C/CHI) multilayer film as a function of the number of deposited 605 pairs of layers. The straight line serves to guide the eye.

Table 1. Minimal inhibitory concentration $\left(\mathrm{MIC}_{100}\right.$ in $\left.\mu \mathrm{M}\right)$ of $\mathrm{CTL}$, CTL-C and HA-CTL-C measured in solution leading to a complete inhibition of pathogens. In the case of HA-CTL-C, the MIC values given correspond to the concentration in CTL-C.

610

\begin{tabular}{cccc}
\hline \multirow{2}{*}{ Pathogens } & \multicolumn{3}{c}{$\mathrm{MIC}_{100}(\mu \mathrm{M}$ in peptide $)$} \\
\cline { 2 - 4 } & $\mathrm{CTL}$ & $\mathrm{CTL}-\mathrm{C}$ & $\mathrm{HA}-\mathrm{CTL}-\mathrm{C}$ \\
\hline S. aureus & 30 & 35 & 45 \\
M. luteus & 5 & 1 & 5 \\
C. albicans & 20 & 20 & 25 \\
\hline
\end{tabular}


Submitted to
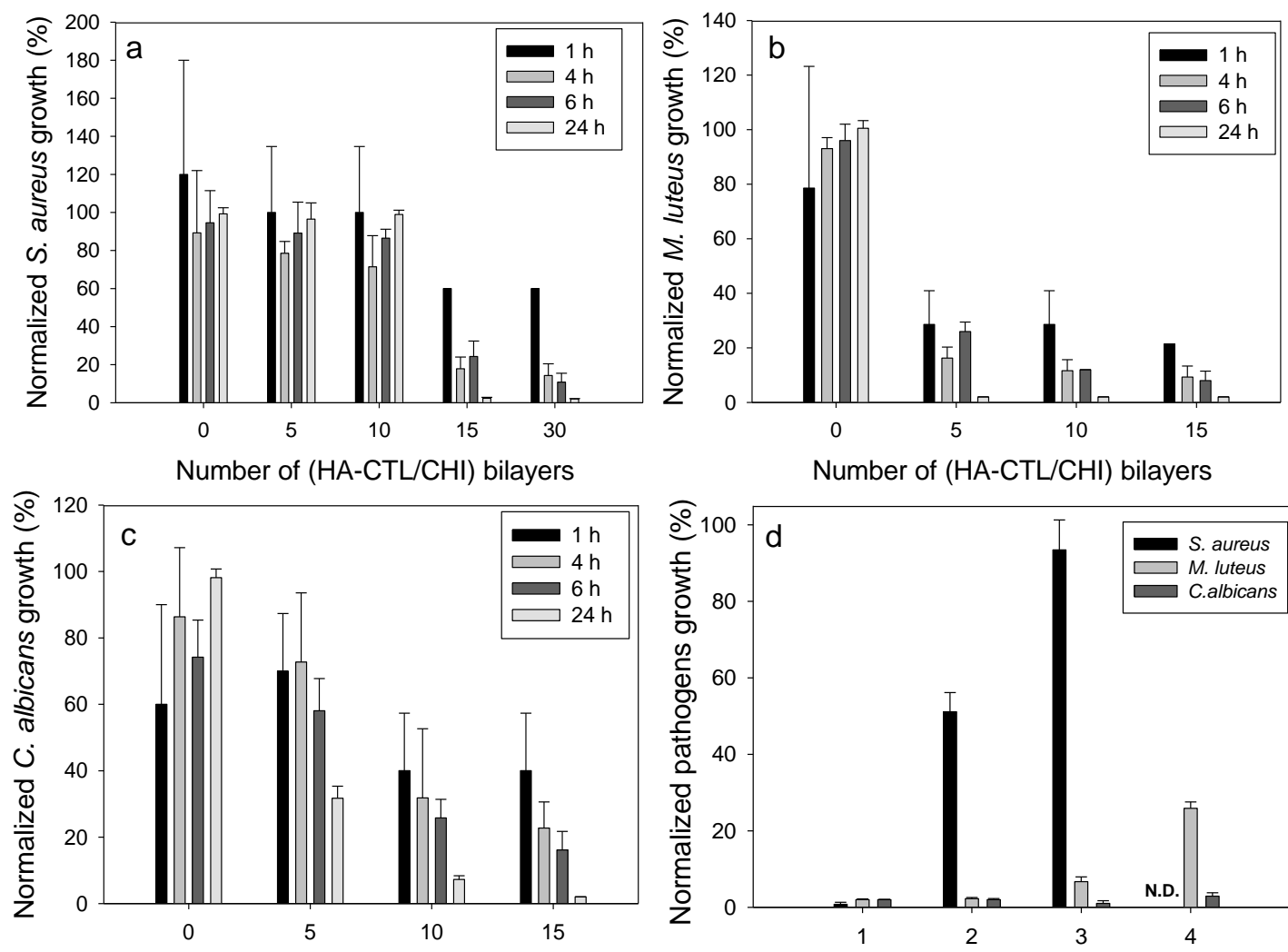

Number of (HA-CTL/CHI) bilayers

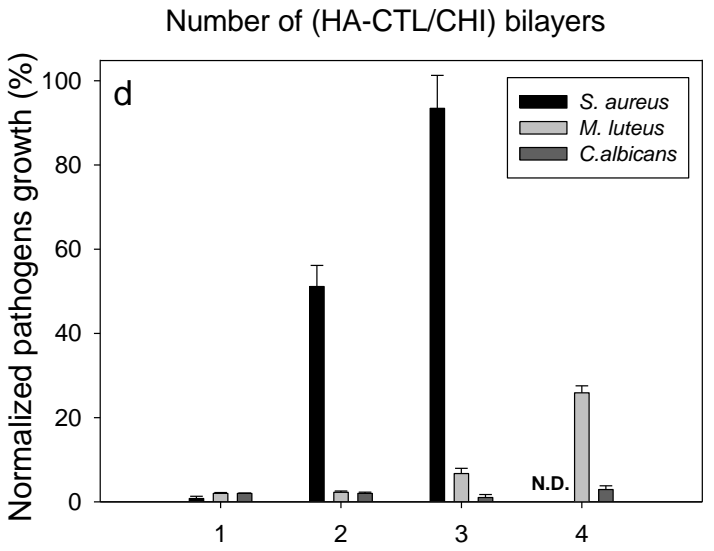

Number of uses

615 Figure 2. Normalized growth of (a) S. aureus, (b) M. luteus and (c) C. albicans incubated for 1 to $24 \mathrm{~h}$ in contact with PEI-(HA/CHI) 15 -n-(HA-CTL-C/CHI) with $n=0$ to 15 and (HACTL-C/CHI) 30 multilayer films. (d) Normalized growth of $S$. aureus incubated on PEI-(HACTL-C/CHI) 30 and $M$. luteus and $C$. albicans incubated on PEI-(HA-CTL-C/CHI) 15 films, as a function of the number of uses. The film was brought in contact with a fresh pathogen 620 suspension for $24 \mathrm{~h}$. Every $24 \mathrm{~h}$, the supernatant is removed and replaced by a fresh suspension and its $\mathrm{OD}_{620}$ is measured. The films were built in $150 \mathrm{mM} \mathrm{NaCl}$ at $\mathrm{pH}$ 4. The normalization was performed with respect to $\mathrm{OD}_{620}$ measured in the absence of film and antibiotics taken as $100 \%$ growth and in the presence of antibiotic taken as $0 \%$ growth. ND means not determined. 


\section{Submitted to

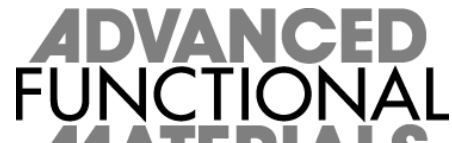 \\ MATERIALS}
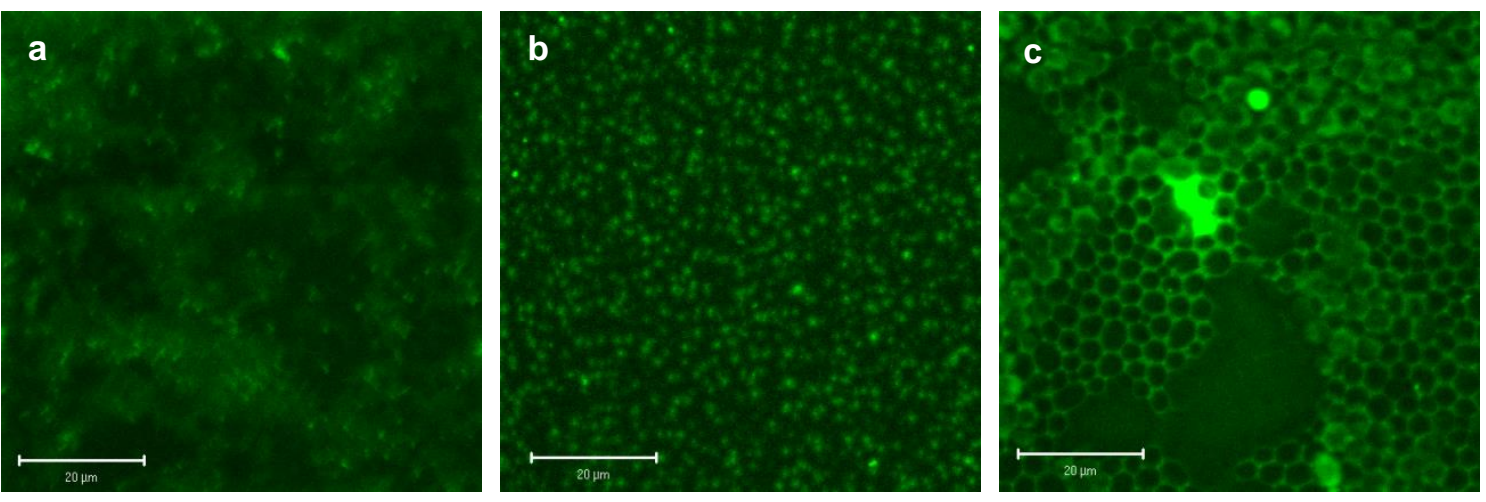

Figure 3. CLSM images of PEI-(HA $\left.{ }^{\mathrm{FITC}} / \mathrm{CHI}\right)_{15}$ after $24 \mathrm{~h}$ of incubation with (a) S. aureus, (b) M. luteus and (c) C. albicans. All the films underwent a PFA treatment. The scale bars represent $20 \mu \mathrm{m}$.
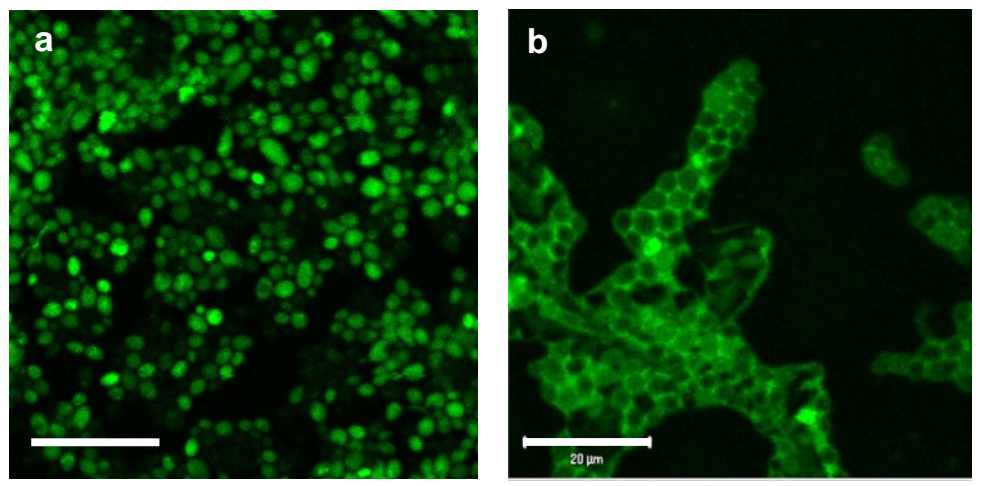

640
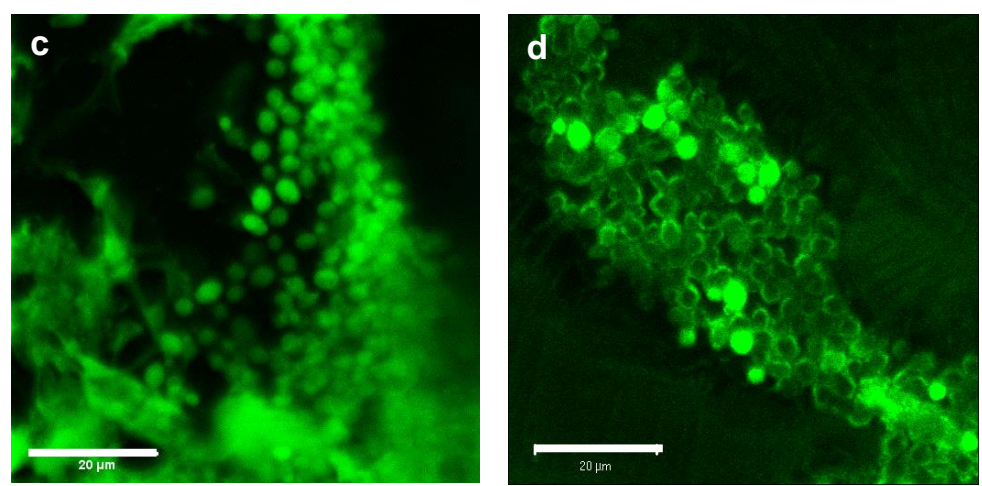

Figure 4. CLSM images of $C$. albicans, after $45 \mathrm{~min}$ of incubation, (a) in the presence of $\mathrm{HA}^{\text {FITC }}$-CTL-C in solution $\left(50 \mu \mathrm{M}\right.$ in peptide), (b) in the presence of $\mathrm{HA}^{\mathrm{FITC}}$ in solution, (c) in contact with PEI-(HA $\left.{ }^{\text {FITC }}-\mathrm{CTL}-\mathrm{C} / \mathrm{CHI}\right)_{15}$ and (d) in contact with PEI-(HA $\left.{ }^{\text {FITC }} / \mathrm{CHI}\right)_{15}$ multilayer films. The scale bars represent $20 \mu \mathrm{m}$. 


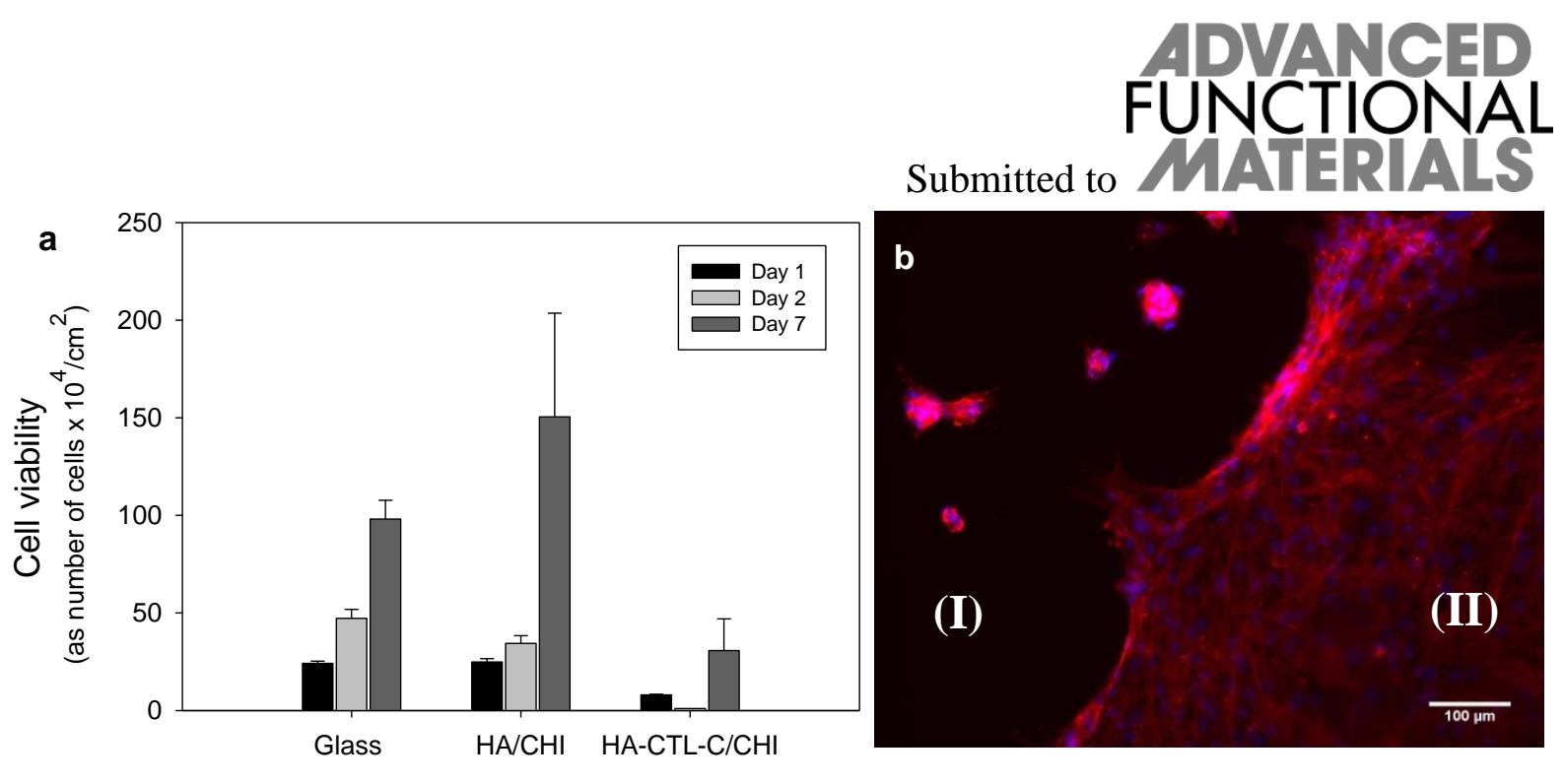

Figure 5. (a) Viability of HGFs, evaluated by metabolic activity of cells, cultured on PEI$(\mathrm{HA} / \mathrm{CHI})_{15}$, named HA/CHI and PEI-(HA-CTL-C/CHI) 15 , named HA-CTL-C/CHI, films built on glass substrates. Cell viability was determined by Alamar Blue ${ }^{\mathrm{TM}}$ assays after 1,2 and 7 days of culture. The values represent the mean and the standard deviation of three films. (b) Cytoskeleton visualization by actin filament immunofluorescent staining with phalloidin ${ }^{\circledR}$ (red labeling) and DAPI nuclei counterstaining (blue labeling) of HGFs after $24 \mathrm{~h}$ of culture on half coated glass substrate by PEI-(HA-CTL-C/CHI) 15 : the areas represent (I) the HACTL-C/CHI film and (II) the bare glass substrate, respectively. 
The table of contents entry:

Submitted to

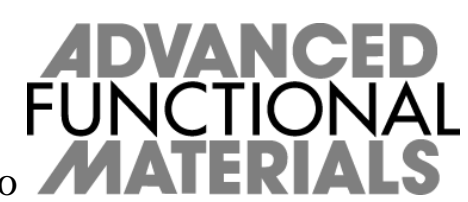

Polysaccharide multilayer films based on antimicrobial peptide functionalized hyaluronic acid

665 as polyanion and chitosan as polycation, is deposited on a planar surface with the aim of designing a self-defensive coating against both bacteria and yeasts.

Keyword: Biomedical Applications

670 G. Cado, R. Aslam, L. Séon, T. Garnier, R. Fabre, A. Parat, A. Chassepot, J.-C. Voegel, B. Senger, F. Schneider, Y. Frère, L. Jierry, P. Schaaf *, H. Kerdjoudj, M.-H. Metz-Boutigue and F. Boulmedais*

Self-defensive biomaterial coating against bacteria and yeasts: polysaccharide multilayer film 675 with embedded antimicrobial peptide

680

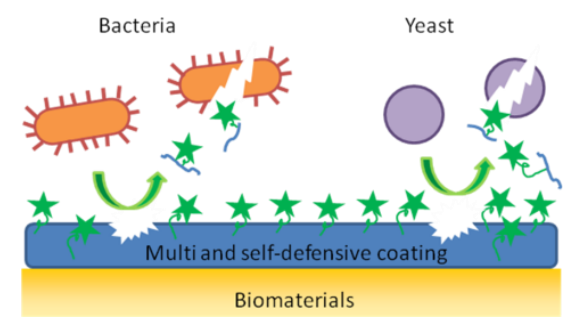




\section{Supporting Information}

685 Self-defensive biomaterial coating against bacteria and yeasts: polysaccharide multilayer film with embedded antimicrobial peptide

G. Cado, R. Aslam, L. Séon, T. Garnier, R. Fabre, A. Parat, A. Chassepot, J.-C. Voegel, B. Senger, F. Schneider, Y. Frère, L. Jierry, P. Schaaf", H. Kerdjoudj, M.-H. Metz-Boutigue and F. Boulmedais*

Abbreviations

1. Preparation and analysis of antimicrobial peptides

2. Preparation of modified HA and PAH

2.1. Preparation of HA-CTL-C

2.2. Preparation of $H A^{F I T C}$

S-30

2.3 Preparation of $H A^{F I T C}-C T L-C$

S-31

2.4 Preparation of $\mathrm{PAH}-\mathrm{CTL}-\mathrm{C}$

3. References

4. Supplementary Figures

Figure $S$-1

Table S-1

$\mathrm{S}-35$

Figure $S$-2

$\mathrm{S}-35$

Figure $S$-3

S-36

Figure $S-4$

S-37

Figure $S$-5

S-38 


\section{Submitted to \\ FUNCTIONAL}

Abbreviations: $\mathrm{AMP}=$ antimicrobial peptides, $\mathrm{CGA}_{344-358}=$ chromogranin A 344-358; CTL = cateslytin; $\mathrm{CHI}=$ chitosan; $\mathrm{CTL}-\mathrm{C}=$ cateslytin with a cystein in $\mathrm{C}$ terminal; $\mathrm{HA}=$ hyaluronic acid; EDC = N-(3-dimethylaminopropyl)-N'-ethylcarbodiimide hydrochloride; sulfo-NHS $=$ N-Hydroxysulfosuccinimide sodium salt; HEPES = 4-(2hydroxyethyl)piperazine-1-ethanesulfonic acid; TCEP $=$ tris(2-carboxyethyl)phosphine hydrochloride; $\mathrm{Da}=$ Dalton; $\mathrm{tBuOH}=$ tertio-butanol; $\mathrm{DS}=$ degree of substitution; $\mathrm{NMR}=$ nuclear magnetic resonance; $\mathrm{MHz}=$ megahertz; $\mathrm{ppm}=$ parts per million $; \mathrm{br}=$ broad; $\mathrm{s}=$ 700 singlet; $\mathrm{d}=$ doublet; $\mathrm{m}=$ multiplet .

\section{Preparation and analysis of synthetic antimicrobial peptides.}<smiles>CCC[C@H](NC(=O)C(CO)NC(=O)[C@H](N)CCCNC(=N)N)C(=O)N[C@@H](CCCNC(=N)N)C(=O)N[C@@H](CC(C)C)C(=O)N[C@@H](CO)C(=O)N[C@@H](Cc1ccccc1)C(=O)N[C@@H](CCCNC(=N)N)C(=O)N[C@@H](C)C(=O)N[C@@H](CCCNC(=N)N)C(=O)NCC(=O)N[C@@H](Cc1ccc(O)cc1)C(=O)NCC(=O)N[C@@H](Cc1ccccc1)C(=O)N[C@@H](CCNC(=N)N)C(=O)N[C@@H](CS)C(=O)O</smiles>

The synthetic peptide corresponding to bovine CGA (Uniprot P05059), named CTL, (CGA 344 358: RSMRLSFRARGYGFR) was synthesized with a cystein at the C-terminal end (CTL-C) on a phase approach with 9-fluorenylmethoxycarbonyl (Fmoc) chemistry. ${ }^{[1]}$ After purification by a Dionex HPLC system (Ultimate 3000; Sunnyvale, CA USA) on a Macherey Nagel Nucleosil RP $300-5 C 18$ column $(10 \times 250 \mathrm{~mm}$; particle size $5 \mu \mathrm{m}$ and pore size $100 \mathrm{~nm})$, the peptide was analyzed by mass spectrometry (MALDI-TOF) and automated Edman sequencing on an Applied Sequencing System Procise (Applied Biosystems, Foster City, USA). ${ }^{[2]}$ MALDI mass measurements were carried out on an Ultraflex ${ }^{\mathrm{TM}}$ TOF/TOF (BrukerDaltonics, USA) to perform a rapid control of synthetic peptides according to the procedure previously reported. ${ }^{[3]}$ 


\section{Preparation of modified HA and PAH.}

Submitted to

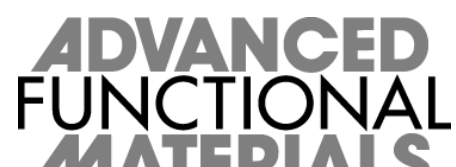

715 Peptide and FITC functionalized HA, i.e. HA-CTL-C, HA ${ }^{\text {FITC }}$ and HA FITC $_{-C T L-C}$, and peptide modified PAH have been prepared according to the general synthetic pathway described below.

\subsection{Preparation of $H A-C T L-C$}

Hyaluronic acid (HA) $420000 \mathrm{Da}$, was functionalized with maleimide group according to previously reported method. ${ }^{[4]}$ HA $(100.9 \mathrm{mg})$ was dissolved in $15 \mathrm{~mL}$ of $0.01 \mathrm{M}$ HEPES buffer (pH 6). EDC (35.2 mg) and sulfo-NHS (10.2 mg) were added to this solution and the resulting mixture was stirred $2 \mathrm{~h}$ at room temperature. Afterwards, N-(2-aminoethyl) maleimide trifluoroacetate salt $(6.7 \mathrm{mg})$ was added to the reaction mixture and let stirred for $20 \mathrm{~h}$. The mixture was dialyzed (cut-off 12 000-14 $000 \mathrm{Da}$ ) first against $0.5 \mathrm{M} \mathrm{NaCl}$ for one day and MilliQ water for 6 days. Water was changed every day. HA-Mal (86 mg) was obtained as a white solid after freeze-drying. The degree of substitution (DS) of HA-Mal, defined as the number of maleimide groups per 100 disaccharide unit of HA, was determined by ${ }^{1} \mathrm{H}$ NMR $\left(\mathrm{D}_{2} \mathrm{O}, 400 \mathrm{MHz}\right)$. All spectra were realized in $\mathrm{D}_{2} \mathrm{O}$ containing $5 \%$ of $t \mathrm{BuOH}$ : the singlet of the $t$-butyl group of $t \mathrm{BuOH}$ was calibrated at $\delta 1.24 \mathrm{ppm}$ and thus used as internal reference. The singulet at $\delta 7.1 \mathrm{ppm}$ was assigned to the two symmetric protons on the double bond of the maleimide group. By comparing the integration of this signal with the singlet at $\delta$ $2.0 \mathrm{ppm}$, assigned to the methyl protons of the acetamide group, the DS was determined equivalent to $5 \%$.

${ }^{1} \mathbf{H}$ NMR (D $2 \mathrm{O}, 400 \mathrm{MHz}, \delta$ ppm): $\delta 6.9$ (s, maleimide), 4.5 (br d, HA), 3.5 (m), 2.0 (s, acetyl group of HA).

The coupling reaction between HA-Mal 5\% (80 mg) and CTL-C (10.1 mg) was performed at $4^{\circ} \mathrm{C}$ for $20^{\circ} \mathrm{h}$ in $16 \mathrm{~mL}$ of $0.01 \mathrm{M}$ HEPES buffer $(\mathrm{pH}$ 6) and $50 \mu \mathrm{M}$ of TCEP. Then, the mixture was dialyzed (cut-off $50000 \mathrm{Da}$ ) against $0.5 \mathrm{M} \mathrm{NaCl}$ for one day and MilliQ water for 6 days. Water was changed every day. Peptide-conjugated HA, named HA-

740 CTL-C, was freeze-dried to provide a white solid with $80-85 \%$ of overall yield ( $\approx 79 \mathrm{mg}$ ). The DS, defined as the number of CTL-C peptide per 100 disaccharide units of HA, was determined by ${ }^{1} \mathrm{H}$ NMR $\left(\mathrm{D}_{2} \mathrm{O}, 400 \mathrm{MHz}\right)$. All aromatic signals between $\delta 7.0$ and $7.5 \mathrm{ppm}$ corresponding to the protons of the aminoacids Phe and Tyr were compared to the singlet at $\delta$ $2.0 \mathrm{ppm}$ (assigned as the methyl group of the acetamide). A DS of 5\% is determined. 

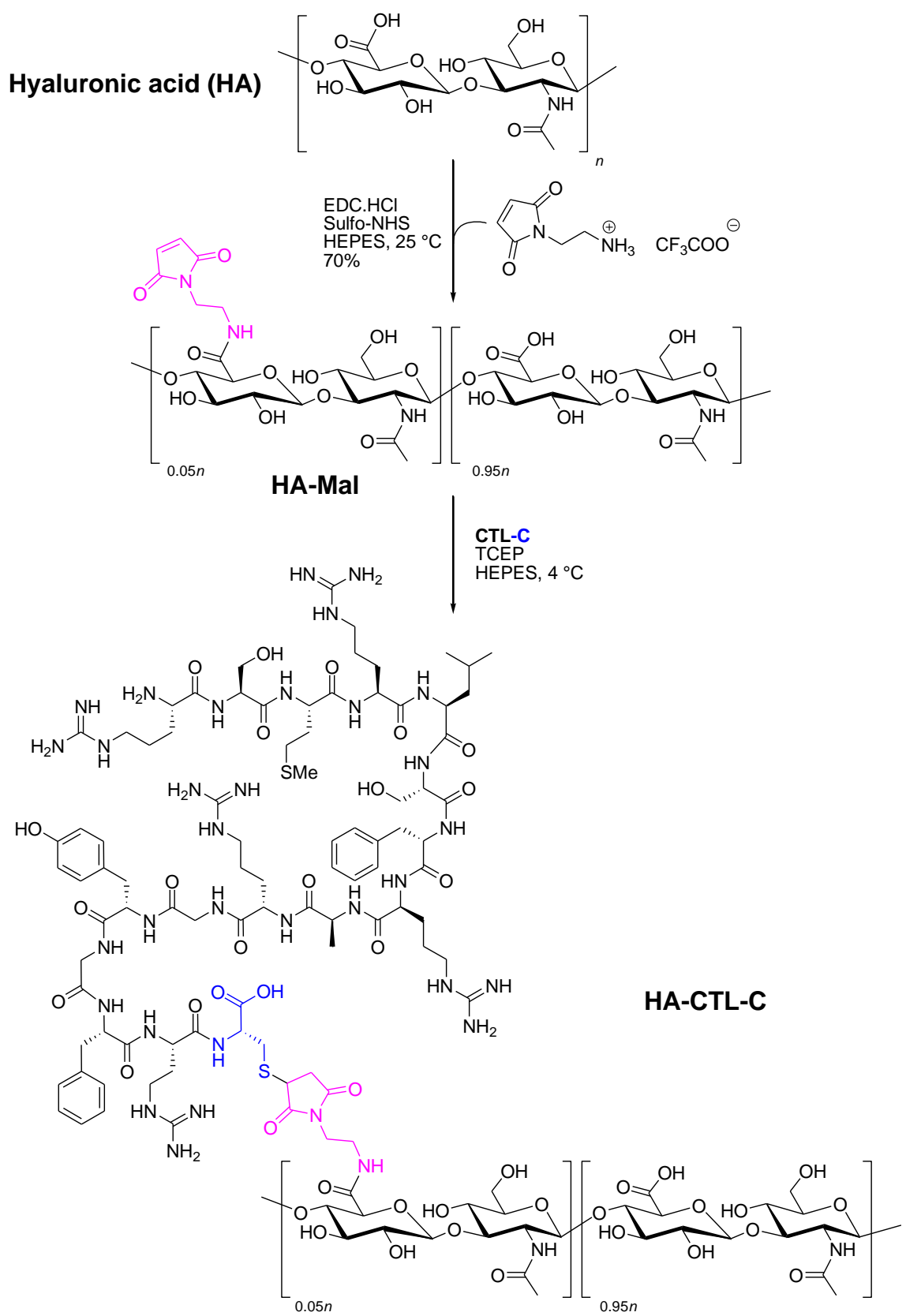

$770{ }^{1} \mathbf{H}$ NMR $\left(\mathrm{D}_{2} \mathrm{O}, 400 \mathrm{MHz}, \delta \mathrm{ppm}\right): 7.35$ (br s, Ar aminoacid of CTL-C), 7.25 (br s, Ar aminoacid of CTL-C), 7.10 (br s, Ar aminoacid of CTL-C), 6.85 (br s, Ar aminoacid of CTLC), 4.50 (br s, HA), 4.40 (br s, CTL-C), 3.10 (br s, CTL-C), 2.50 (br s, CTL-C), 2.00 (s, methyl from acetyl group of HA), 1.75 (br s, CTL-C), 0.95 (br s, CTL-C).

\subsection{Preparation of $H A^{\text {FITC }}$}

775 Fluorescein Isothiocyanate (FITC) has been covalently attached to HA according to the following procedure: a solution of FITC (41 $\mu \mathrm{mol}$ dissolved in $2 \mathrm{~mL}$ of DMSO) and a solution of HA $(0.31 \mu \mathrm{mol}$ dissolved in $18 \mathrm{~mL}$ of deionized water $)$ were mixed. The resulting solution was then adjusted at $\mathrm{pH} 9$ by using a $0.01 \mathrm{M} \mathrm{NaOH}$ solution. The reaction mixture 
Submitted to

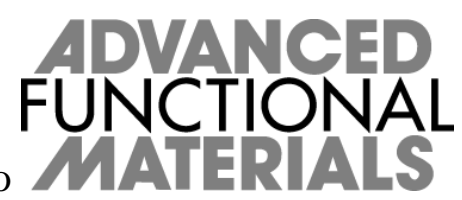

was stirred for $12 \mathrm{~h}$ at room temperature. Then, $40 \mathrm{~mL}$ of deionized water was added and this

final mixture was dialyzed (cut-off: 12000 - 14000 Da) against deionized water until no absorbance was detected in the water $(\lambda=494 \mathrm{~nm})$. The obtained compound is a yellowish solid and corresponds to functionalized $\mathrm{HA}$ by $1 \%$ of fluorescein. The $1 \mathrm{H}$ NMR $\left(\mathrm{D}_{2} \mathrm{O}\right)$ spectra of $\mathrm{HA}^{\text {FITC }}$ is identical to the non-modified HA. Because of the very low loading of fluorescein on $\mathrm{HA}$, the ${ }^{1} \mathrm{H}$ NMR $\left(\mathrm{D}_{2} \mathrm{O}\right)$ spectra of $\mathrm{HA}^{\mathrm{FITC}}$ is identical to the non-modified HA.

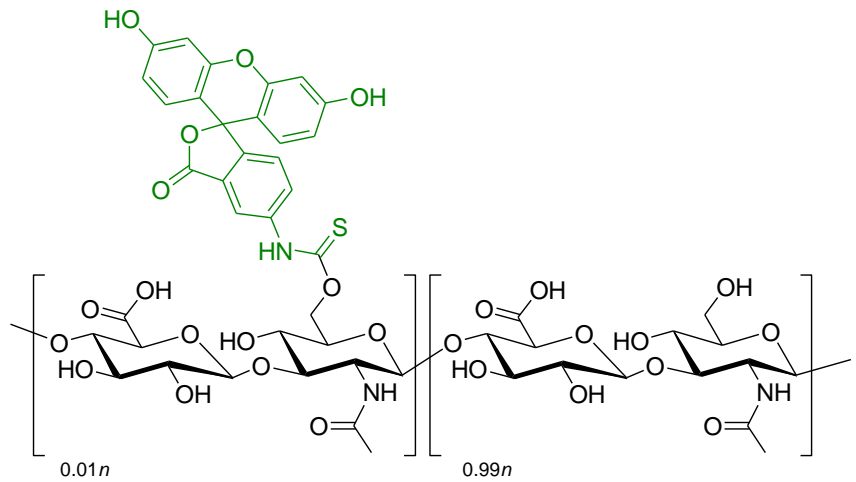

790

$\mathrm{HA}^{\mathrm{FITC}}$

The fluorescein moiety may also be linked through the secondary alcohol groups.

2.3. Preparation of $H A^{F I T C}-C T L-C$

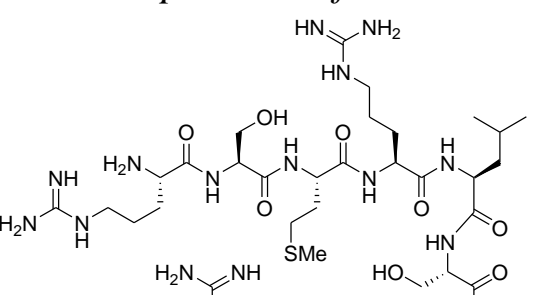

800

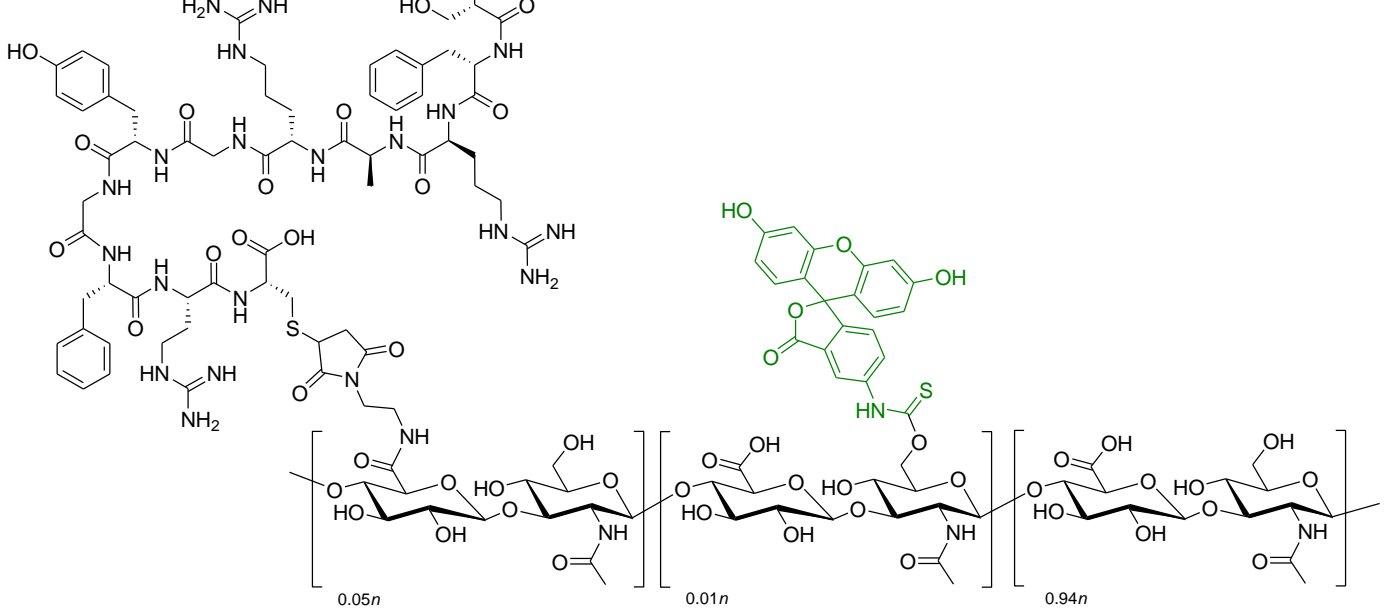

HA $^{\text {FITC-CTL }}$

The fluorescein moiety may also be linked through the secondary alcohol groups.

HA $^{\text {FITC }}$-CTL-C polymer has been prepared from HA-Mal. This polymer was labeled with $1 \%$

FITC as described above to provide $\mathrm{HA}^{\mathrm{FITC}}$-Mal. Then, CTL-C peptide reacted with free maleimide group to lead to $\mathrm{HA}^{\mathrm{FITC}}-\mathrm{CTL}-\mathrm{C}$ as a yellow solid. The procedure used to get 
Submitted to $\mathrm{HA}^{\text {FITC }}$-CTL-C was identical to the one described above to prepare HA-CTL-C. ${ }^{1} \mathrm{H}$ NMR $\left(\mathrm{D}_{2} \mathrm{O}\right)$ spectra of $\mathrm{HA}^{\mathrm{FITC}}-\mathrm{CTL}-\mathrm{C}$ was identical to the spectra of HA-CTL-C.

\subsection{Preparation of PAH-CTL-C}

810 All the following reactions were carried out in NMR tube and monitored by ${ }^{1} \mathrm{H} N M R\left(\mathrm{D}_{2} \mathrm{O}\right)$. To a solution of PAH $(22.16 \mathrm{mg})$ in $\mathrm{D}_{2} \mathrm{O}(0.6 \mathrm{~mL})$ was added Mal-OSu $(15 \mathrm{mg})$. The resulting mixture was stirred mechanically at room temperature until RMN monitoring indicated total consumption of the reagent $(48 \mathrm{~h})$. Evaporation of solvent provided the desired PAH-Mal $(27 \mathrm{mg})$ as a white solid which was used without further purification. The DS of PAH-Mal was determined by ${ }^{1} \mathrm{H}$ NMR $\left(400 \mathrm{MHz}, \mathrm{D}_{2} \mathrm{O}\right)$ and defined as the number of maleimide groups per 100 allylamine units of PAH. NMR Spectrum was realized in $\mathrm{D}_{2} \mathrm{O}$ and calibrated at $\delta 4.79 \mathrm{ppm}$ (residual water). The singulet at $\delta 6.9 \mathrm{ppm}$ was assigned to the two symmetric protons on the double bond of the maleimide group. By comparing the integration of this signal with the singlet at $\delta 3.1 \mathrm{ppm}$, assigned to the $\mathrm{C}_{2}-\mathrm{NH}$ protons of the allylamine group, the DS was determined equivalent to $10 \%$.

${ }^{1} \mathrm{H}$ NMR $\left(\mathrm{D}_{2} \mathrm{O}, 400 \mathrm{MHz}, \delta \mathrm{ppm}\right): \delta 6.9$ (s, maleimide), 3.8 (t, Mal- $\underline{\mathrm{H}}_{2}-\mathrm{CH}_{2}-\mathrm{CO}$ ), 3.1 (br s, $\mathrm{CH}_{2}$ of $\mathrm{PAH}$ ), 2.7 (t, Mal- $\mathrm{CH}_{2}-\underline{\mathrm{C}}_{2}-\mathrm{CO}$ ), 2.1 (br s, $\mathrm{CH}$ of $\left.\mathrm{PAH}\right), 1.6$ (br s, $\mathrm{CH}_{2}$ of PAH).

825
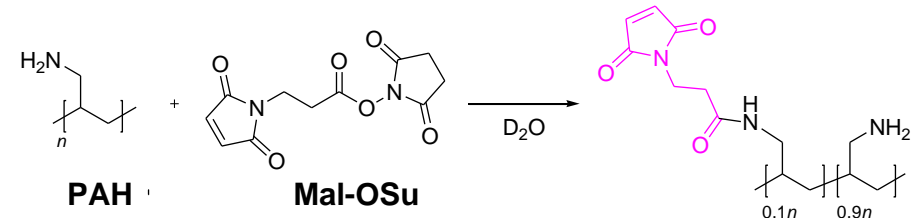

\section{PAH-Mal}

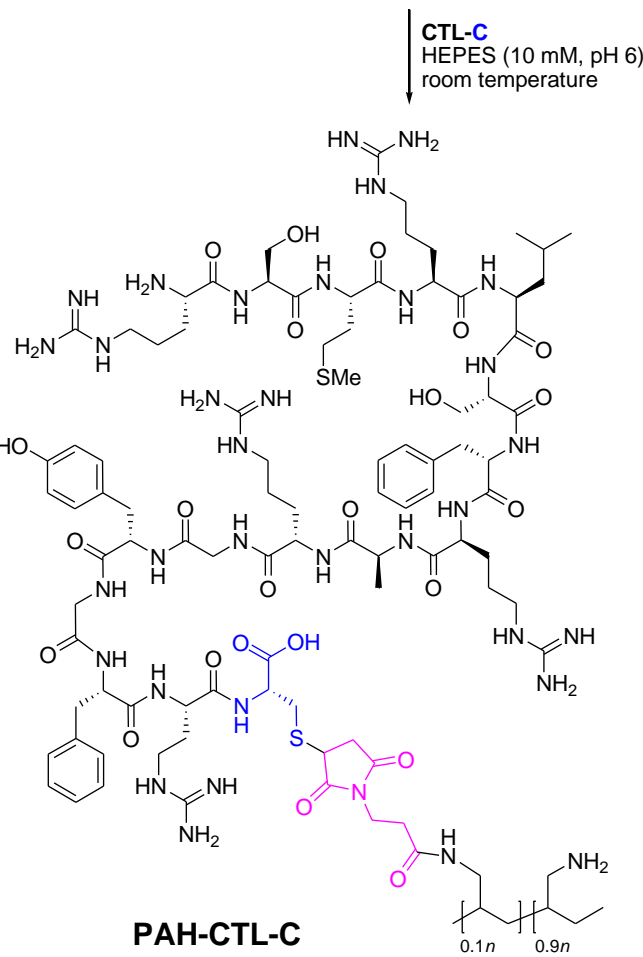


Submitted to

The coupling reaction between PAH-Mal 10\% (1.5 mg) and CTL-C (15.6 mg) was performed overnight at room temperature in $0.6 \mathrm{~mL}$ of $10 \mathrm{mM}$ HEPES buffer solution in $\mathrm{D}_{2} \mathrm{O}(\mathrm{pH}$ 6). Then, the mixture was dialyzed (cut-off: 12000 - 14000 Da) against MilliQ water for 6 days (water was changed every day). Peptide-conjugated PAH, named PAH-CTL-C, was freeze

840 dried to provide a white solid (17 mg). This quantitative yield and the ${ }^{1} \mathrm{H}$ NMR described below allowed us to define a 10\% DS (number of CTL-C peptide per 100 allylamine units of PAH).

${ }^{1} \mathbf{H}$ NMR $\left(\mathrm{D}_{2} \mathrm{O}, 400 \mathrm{MHz}, \delta \mathrm{ppm}\right): 7.35$ (br s, Ar aminoacid of CTL-C), 7.25 (br s, Ar aminoacid of CTL-C), 7.13 (br s, Ar aminoacid of CTL-C), 6.86 (br s, Ar aminoacid of CTL845 C), 3.67-4.68 (m, CTL-C), 3.10 (br m, PAH and CTL-C), 2.50-2.68 (br m, CTL-C), 1.34-2.18 (br m, PAH and CTL-C), 0.96 (br s, CTL-C).

\section{References}

[1] R. B. Merrifield, Science 1965, 150, 178.

[2] M.-H. Metz-Boutigue, Y. Goumon, K. Lugardon, J. M. Strub, D. Aunis, Cell. Mol. 850 Neurobiol. 1998, 18, 249.

[3] D. Sizova, E. Charbaut, F. Delalande, F. Poirier, A. A. High, F. Parker, A. Van Dorsselaer, M. Duchesne, A. Diu-Hercend, Neurobiol. Aging 2007, 28, 357.

[4] S. T. Wall, K. Saha, R. S. Ashton, K. R. Kam, D. V. Schaffer, K. E. Healy, Bioconjug. Chem. 2008, 19, 806. 


\section{Supplementary Figures}

Submitted to MATIONA

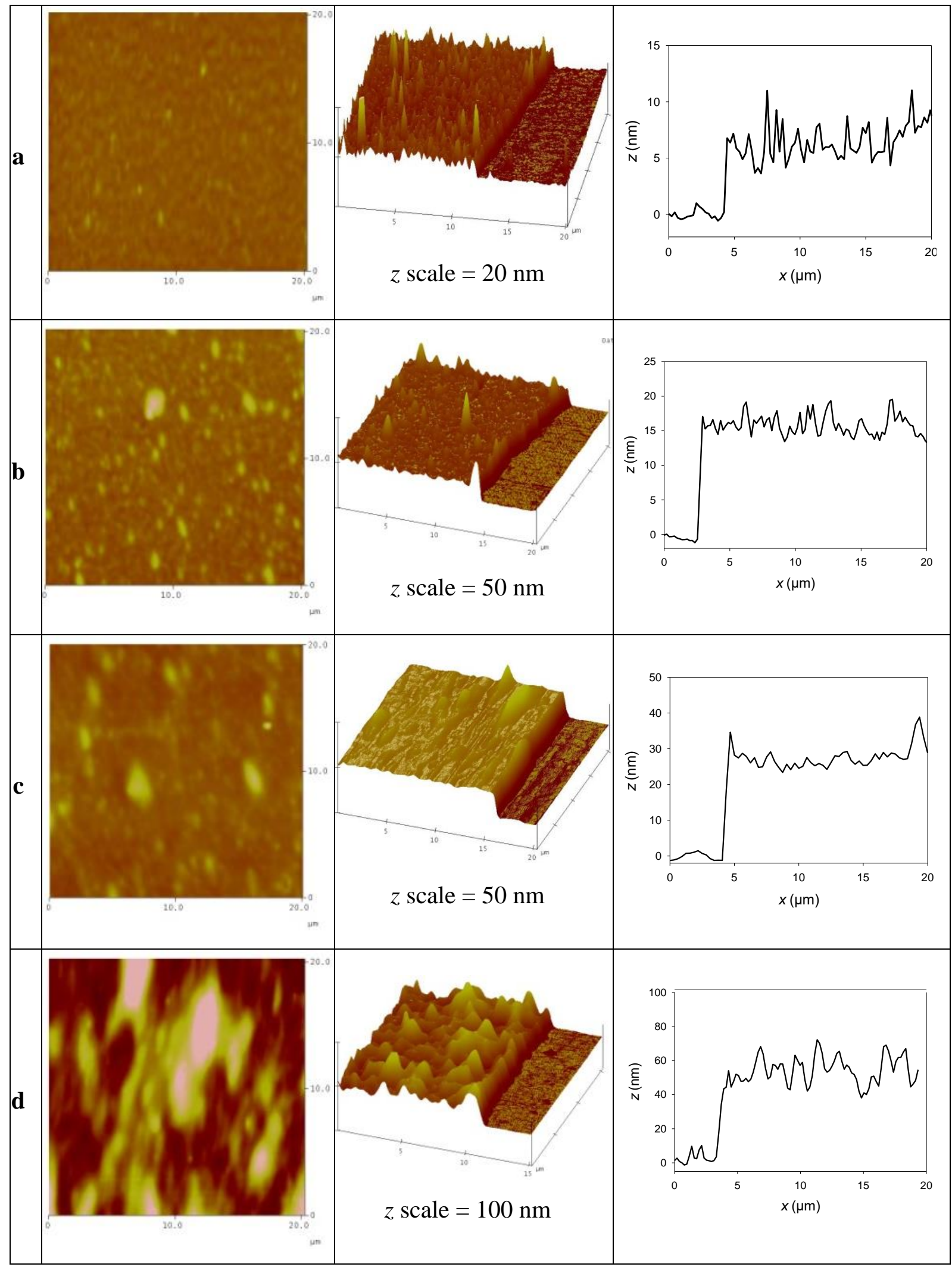

Figure S-1: AFM images of non-scratched and 3D images and their profilometric sections of scratched PEI(HA-CTL-C/CHI) films built at (a) 5, (b) 10, (c) 15 and (d) 30 bilayers obtained in height mode in dry state. 
Submitted to

Table S-1. Thicknesses and roughnesses of PEI-(HA-CTL-C/CHI) films built at different number of deposited pair of layers, $n$. The errors on the thickness values measured by AFM were obtained from the measurement of three different areas.

\begin{tabular}{ccc}
\hline $\boldsymbol{n}$ & $\boldsymbol{d}_{\mathrm{AFM}}(\mathbf{n m})$ & RMS $(\mathbf{n m})$ \\
\hline 5 & $5 \pm 1$ & $1.6 \pm 0.1$ \\
10 & $17 \pm 2$ & $4.2 \pm 0.8$ \\
15 & $28 \pm 3$ & $4.6 \pm 0.9$ \\
30 & $52 \pm 9$ & $16.5 \pm 2.8$ \\
\hline
\end{tabular}

865

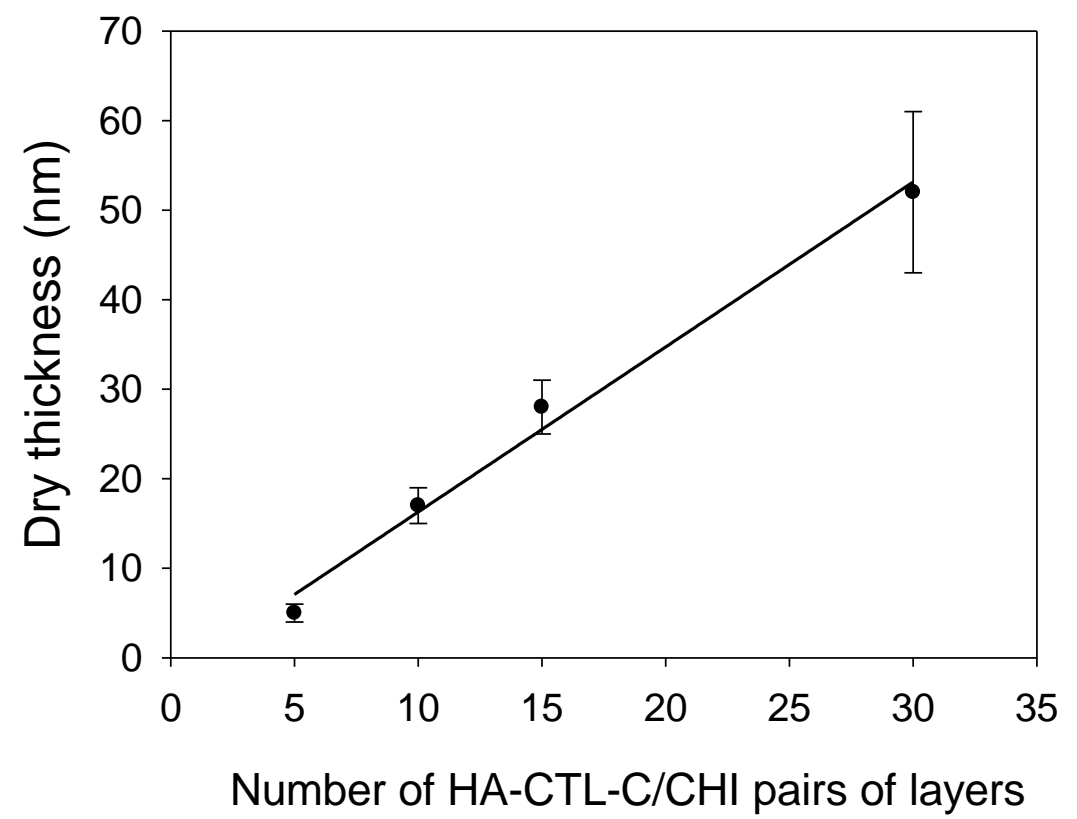

Figure S-2: Evolution of the thickness of (HA-CTL-C/CHI) films, measured by AFM in dry state after scratching, at different number $n$ of pairs of layers. 


\section{Submitted to \\ FUNCTIONAL}

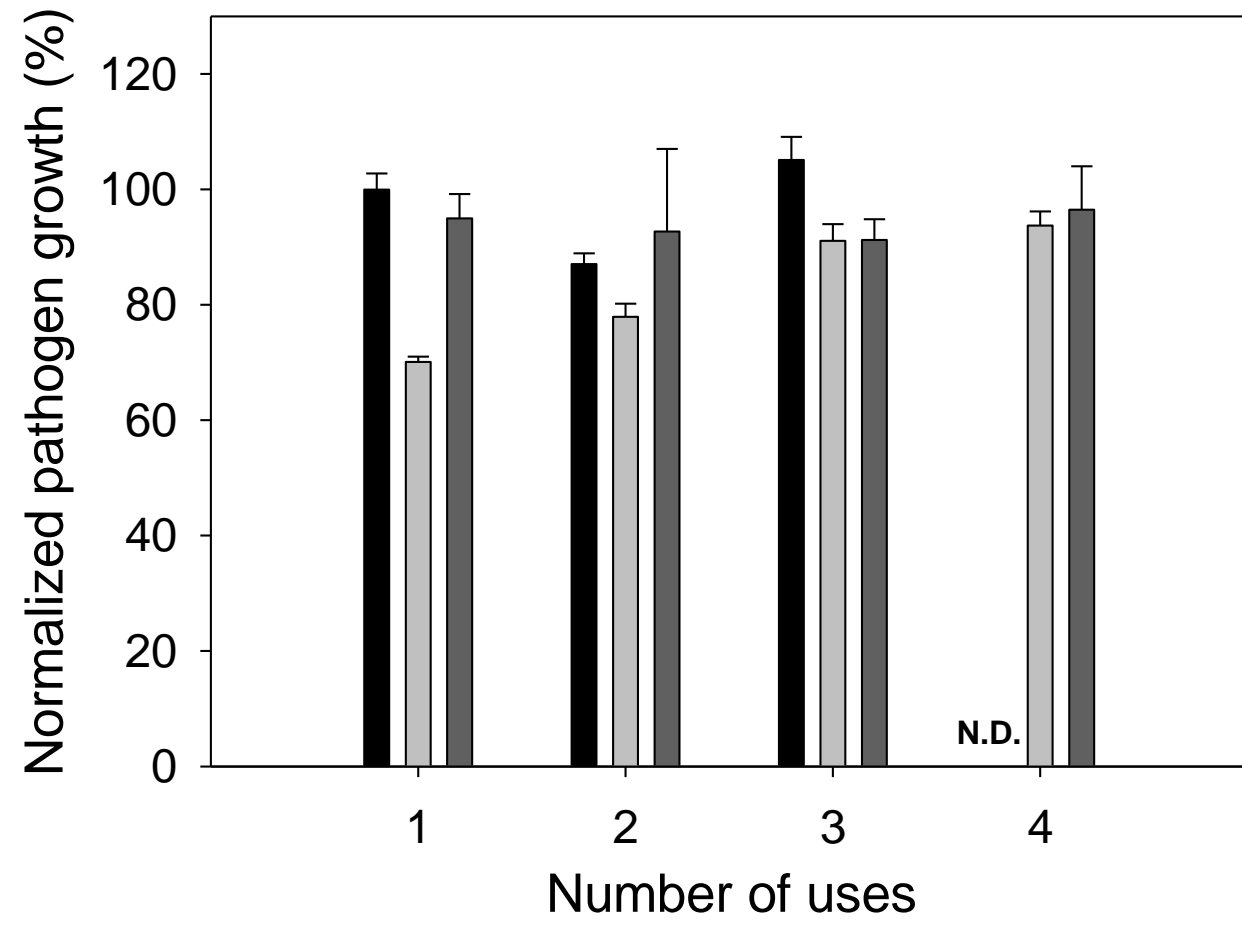

S. aureus

M. luteus

C.albicans

\section{Number of uses}

Figure S-3: Normalized growth of S. aureus, M. luteus and C. albicans, incubated for $24 \mathrm{~h}$ in contact with the supernatant withdrawn from HA-CTL-C/CHI films used in Figure 2d. Every $24 \mathrm{~h}$, the film was put in contact with a fresh pathogen suspension. After $24 \mathrm{~h}$ of incubation with the film, the supernatant was withdrawn and incubated for $24 \mathrm{~h}$ with a fresh pathogen suspension. The normalization was performed with respect to $\mathrm{OD}_{620}$ measured in the absence of film and antibiotics taken as $100 \%$ growth and in the presence of antibiotic taken as $0 \%$ growth. ND means not determined. 


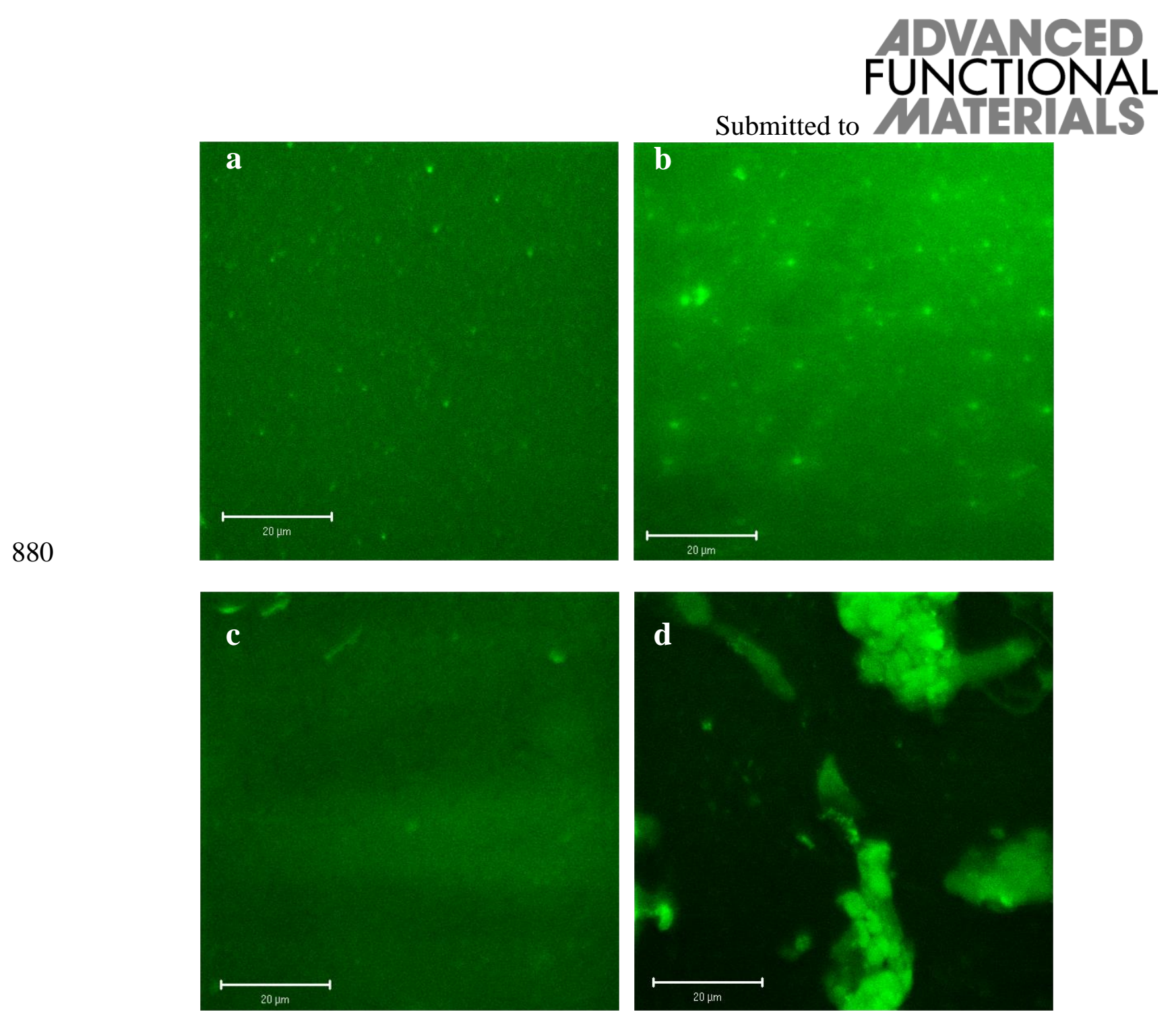

Figure S-4: CLSM images of PEI-(HA $\left.\mathrm{HATC}^{\mathrm{FIT}} \mathrm{CHI}\right)_{15}$ (a) before and (b) after paraformaldehyde (PFA) treatment and of PEI-(HA FITC $\left._{-} \mathrm{CTL}_{-} \mathrm{C} / \mathrm{CHI}\right)_{15}$ (c) before and (d) after PFA treatment. PFA treatment was performed to allow the observation of polysaccharide multilayer films after contact with pathogens. The films are put into 885 contact for 30 min with $4 \%$ paraformaldehyde in phosphate buffer saline (PBS) at pH 7.3 and, after several rinsing with PBS, were covered with Moviol 4-88 (Aldrich, Steinheim, Germany). The scale bars represent 20 $\mu \mathrm{m}$. 
Submitted to

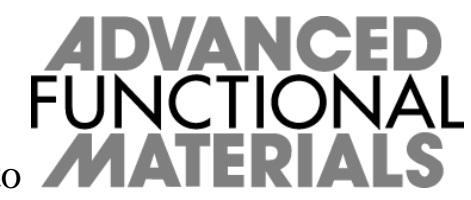

$\mathbf{a}$

\section{b}

890
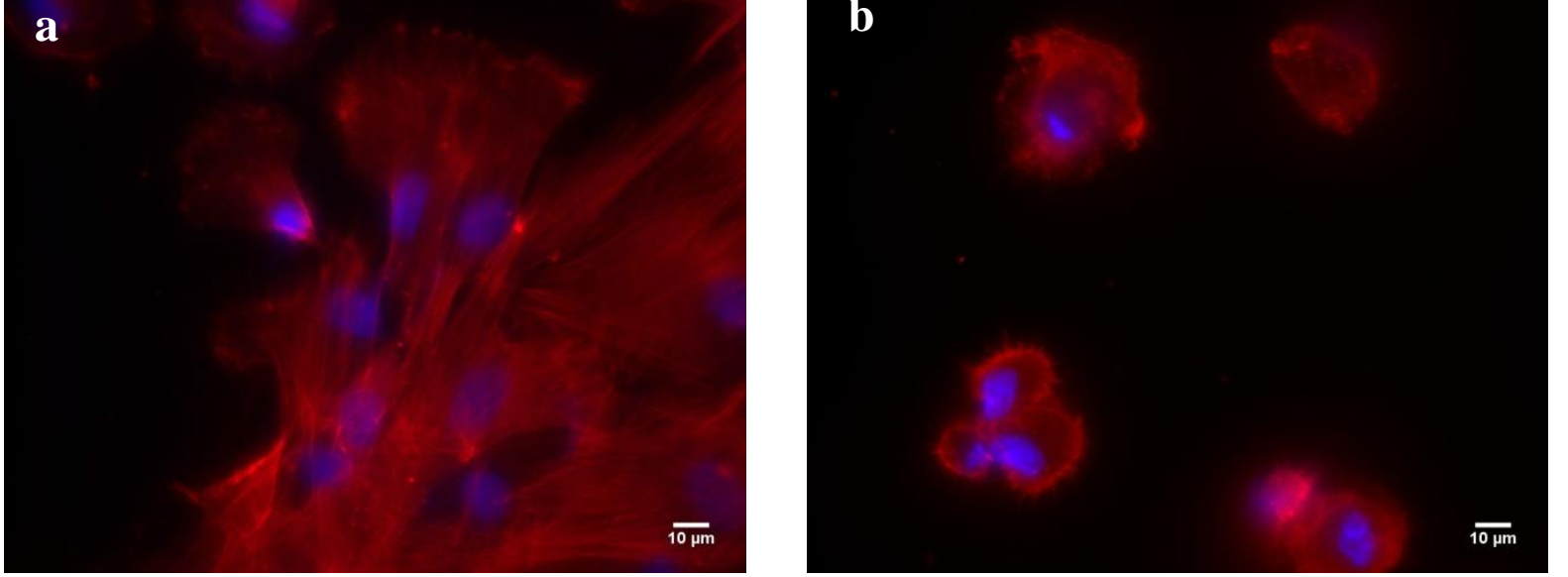

895 Figure S-5: Immunolabeling of HGFs after $24 \mathrm{~h}$ of culture on (a) a glass substrate and (b) on PEI-(HA-CTL$\mathrm{C} / \mathrm{CHI})_{15}$ film. The cytoskeleton was visualized by actin filament immunochemistry staining with phalloidin ${ }^{\circledR}$ (red labeling) and the nuclei with DAPI counterstaining (blue labeling) of HGFs. The scale bars represent $10 \mu \mathrm{m}$. 